
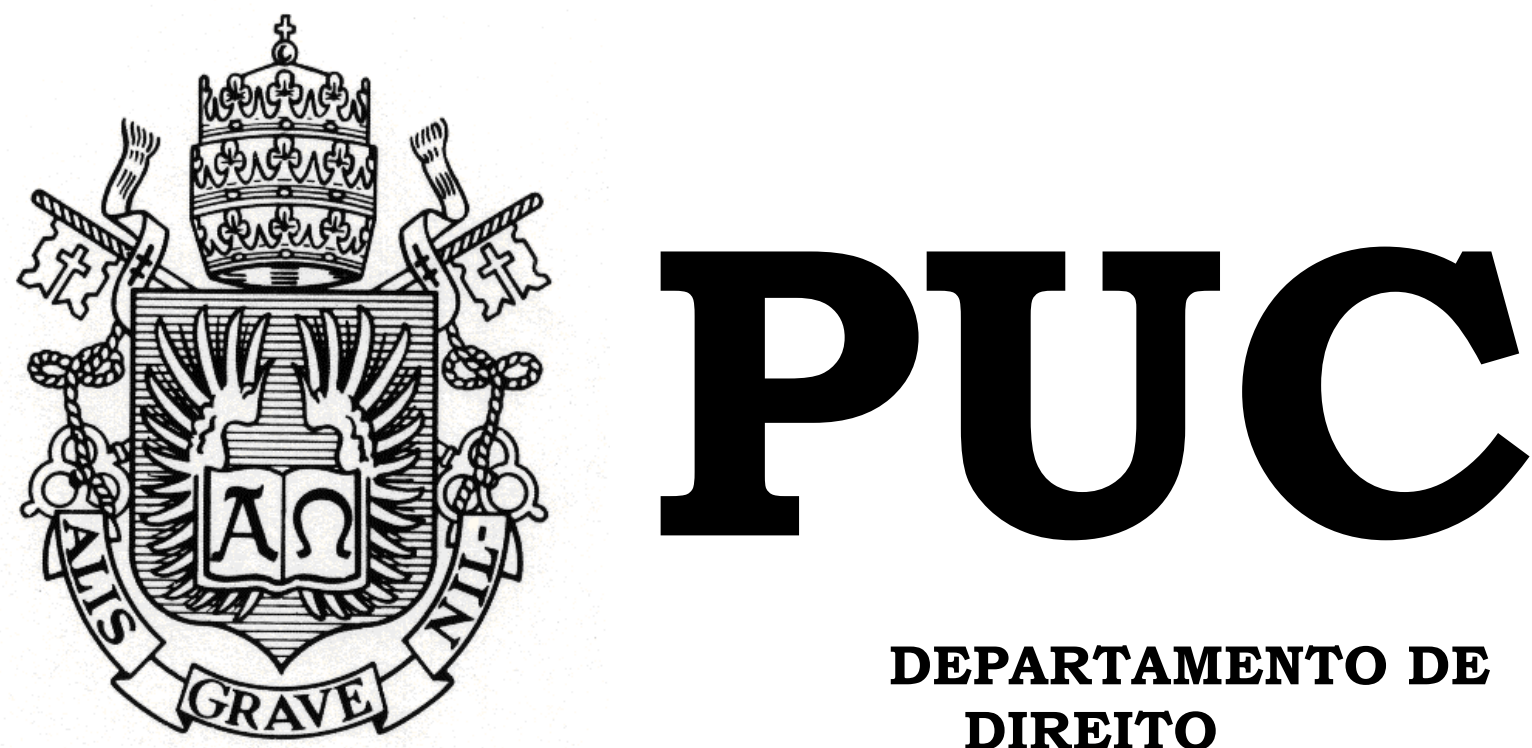

DEPARTAMENTO DE DIREITO

\title{
UM OLHAR SOBRE A PORNOGRAFIA: teoria e perspectivas juridicas
}

por

Ana Luiza Ramos Fernandes

ORIENTADOR(A): Thamis Dalsenter

2017.1

PONTIFÍCIA UNIVERSIDADE CATÓLICA DO RIO DE JANEIRO

RUA MARQUÊS DE SÃO VICENTE, 225 - CEP 22453-900

RIO DE JANEIRO - BRASIL 


\title{
UM OLHAR SOBRE A PORNOGRAFIA: teoria e perspectivas juridicas
}

\author{
por
}

Ana Luiza Ramos Fernandes

Monografia apresentada ao Departamento de Direito da Pontifícia Universidade Católica do Rio de Janeiro (PUC-Rio) como requisito parcial para a obtenção do Título de Bacharel em Direito.

Orientador(a): Thamis Dalsenter 


\section{Resumo}

O presente trabalho visa apresentar uma visão sobre o impacto da pornografia nas dinâmicas relacionais de gênero, mais especificamente no que tange a violência sexual contra a mulher. Parte-se de uma análise inicial sobre a forma com que teoria feminista transportou a sexualidade de um âmbito privado intocável até o âmago da discussão política, para, enfim, desembocar no tema central desta investigação. Este trabalho procura dimensionar as interações entre poder, autonomia e desejo para pensar o caráter atuante da pornografia na conformação de uma realidade desigual entre homens e mulheres. Através das visões proporcionadas pelas feministas militantes Andrea Dworkin e Catharine Mackinnon, busca-se discutir do papel do Direito neste cenário, deslocando tal reflexão para a conjuntura brasileira atual.

Palavras chave: pornografia; violência de gênero, autonomia; violência sexual. 


\section{Sumário}

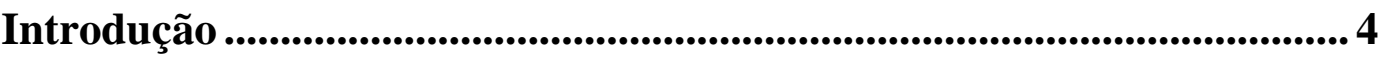

1 Deslocamentos na noção de autonomia ........................................ 7

1.1 A influência do pensamento liberal clássico e contemporâneo na delimitação entre público e privado.........................................................

1.2 Introdução à crítica feminista: a presença da opressão de gênero na oposição público-privado....................................................................... 13

1.3 A problemática na formulação de preferências subjetivas ............. 19

2 Ao centro do debate sobre pornografia........................................... 23

2.1 Contextualizando o ativismo feminista anti-pornografia................ 23

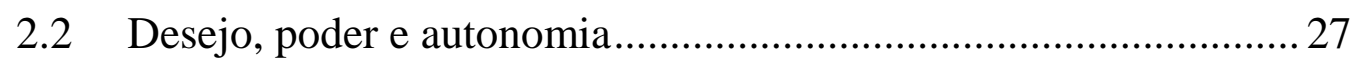

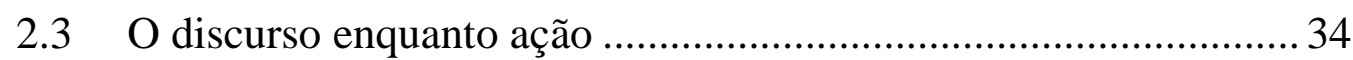

2.4 Uma roupagem legal à pornografia: a proposta do combate ......... 42

3 Olhares jurídicos sobre o pornô no Brasil ............................................. 48

3.1 O que há de novo na pornografia: alcances e influências

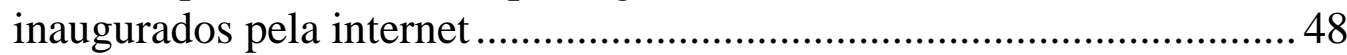

3.2 O cenário legal atual da pornografia ..............................................57

3.3 Proposições reflexivas sobre o tema ................................................ 62

Considerações Finais ........................................................................................ 66

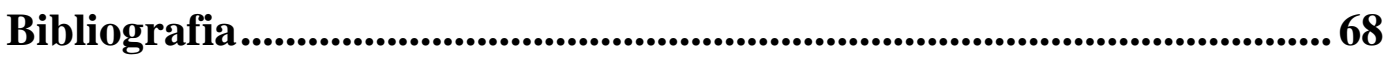




\section{Introdução}

A pornografia é um tema espinhoso. Como afirmar que o acesso a determinado material sexualmente explícito pode levar a naturalização de práticas violentas contra a mulher? Do outro lado, como defender que uma pornografia que erotiza a objetificação e dor feminina nada tem a ver com o cenário de violência sexual com o qual nos deparamos hoje? As respostas esboçadas parecem polarizar em sentidos opostos, vez que a medida exata da influência da pornografia sobre a realidade é de difícil mensura. Sequer podemos contar com um suporte empírico que aponte em alguma direção, pois pouco se pesquisa ou debate sobre o tema. Neste impasse, buscar restringir seu conteúdo soa como um ato radical, mas ignorar seu caráter influente também é negligenciar a situação-alarme em que se encontra a mulher nesta sociedade. Afinal, no Brasil notifica-se um caso de estupro a cada 11 minutos, $89 \%$ deles com vítimas mulheres.

Desde os anos oitenta, auge da produção teórica feminista sobre o tema, a pornografia teve seu meio de divulgação substancialmente alterado com o surgimento da internet. Com rápido e irrestrito acesso a sites de conteúdo pornográfico, em sua maioria acessados por homens entre 18 e 24 anos, a discussão sobre pornografia ganha outra dimensão de relevância prática. A internet tornou ainda mais complexa a análise sobre o tema, adicionando novas dinâmicas de produção e delimitando outros níveis de alcance em seu consumo. A partir desta conjuntura, é necessário convidar à reflexão sobre a importância da se inserir a pornografia na pauta de debate atual.

Este trabalho assume uma leitura possível e parcial sobre a correlação entre pornografia e violência de gênero, passando pela investigação da autonomia da mulher neste quadro. Guiar esta análise com as teses antipornografia de Catharine MacKinnon e Andrea Dworkin trata-se de uma escolha pessoal. A Direito olha a pornografia? Diante de uma resposta negativa, utilizar a obra das autoras parece ideal para lançar uma perspectiva jurídica e política sobre o tema. A violência sexual é uma das mais bárbaras, 
inassimiláveis formas de opressão contra a mulher. $\mathrm{O}$ horror, a irreversibilidade e o receio da experiência do abuso e da agressão enquanto mulher direcionam minha visão neste debate. Observo o tema com a gravidade de quem sente medo. Se pressuponho que a violência sexual possui múltiplas causas, e há urgência em tratá-la, passo a acreditar que a pornografia não só deveria ser foco de discussão, como não poderia ser diferente.

Trata-se de difícil tarefa a de costurar os argumentos deste trabalho. Somada a pouca literatura brasileira sobre o tema, são precários os dados sobre o estado atual do consumo de pornografia no Brasil. A pornografia, como um todo, parece obscurecida enquanto debate de relevância política. Buscou-se, aqui, criar um caminho que levasse dos pressupostos teóricos que permitiram discussão sobre a sexualidade, à visão feminista anti-pornografia até, por fim, alcançar uma reflexão sobre cenário legal atual brasileiro.

No primeiro capítulo é apresentado o paradigma liberal ocidental que sustentou a dicotomia entre público e privado, suas bases ideológicas e concepções estatais. A forma com que a autonomia foi compreendida por este ideiário sugeria uma oposição indivíduo-Estado. Na esfera pública, âmbito do exercício da cidadania, o Estado possuía atuação direta e legítima. Na ordem privada, ao contrário, regia apenas a vontade do indivíduo, sendo a interferência do Estado absolutamente indesejada. Elucida-se de que forma a teoria crítica feminista denunciou o recorte de gênero envolvendo a distinção entre público e privado. A divisão entre as esferas de atuação isolou a mulher do debate político por mais de uma via. As críticas da feminista Carole Pateman sobre a delimitação público versus privado são elucidadas para fins de ilustração desse movimento. A partir da ruptura com tais pressupostos, a política adentra o privado, e a intimidade e sexualidade tornam-se alvo de discussão.

Surge, neste terreno, o debate sobre pornografia. O segundo capítulo busca situar historiacamente a controvérsia envolvendo o tema, e em seguida assume a diretriz anti-pornografia deste trabalho. Pretende-se explicitar as 
teses de MacKinnon e Dworkin sobre a configuração da pornografia dentro de uma sociedade patriarcal, e centralizar a sexualidade no exercício das opressões de gênero. São explicadas as relações possíveis entre desejo e poder valendo-se de uma abordagem substantiva sobre a autonomia da mulher, segundo a qual a escolha feminina em uma sociedade desigual é afetada pela internalização de normas e padrões opressivos. Demonstra-se que esta vertente feminista acredita que a pornografia não só endossa quanto atua na discriminação de gênero, produzindo efeitos reais. Os projetos de lei de Dworkin e MacKinnon que visavam o combate à pornografia também são analisados neste momento.

Por fim, com base nos pressupostos da corrente feminista escolhida, a pornografia na atualidade é explorada. Observa-se as tendências da pornografia disponível na internet, oferecendo uma interpretação sobre o seu conteúdo. O olhar de inspiração crítica é transportado para o Brasil. Avaliase o panorama dos direitos sexuais no país, bem como o estado da discussão sobre pornografia no cenário legal atual. Por fim, são sugeridas reflexões sobre a relevância de se inserir a pornografia como foco de deliberação na tentativa de se harmonizar as desigualdades existentes entre homens e mulheres. 


\section{Deslocamentos na noção de autonomia}

\subsection{A influência do pensamento liberal clássico e contemporâneo na delimitação entre público e privado}

Por muito tempo valeu-se o ordenamento jurídico nacional de uma rígida fronteira entre a esfera pública e privada para delimitar a margem de atuação do Estado sobre a vida do cidadão. Do início ao fim do século XX, verificou-se no Direito brasileiro um movimento de derrocada de tais estreitos parâmetros de delimitação, flexibilizados predominantemente após a Constituição Federal de 1988, que contavam com uma esfera particular absolutamente impenetrável pelo Estado e um âmbito público regulável pelo mesmo.

Ancorada em uma tradição filosófica liberal, a noção clássica de autonomia ajudou a erigir o que seria este domínio privado das relações particulares, dimensão de livre e irrefreável atuação do sujeito. Por trás desta concepção de autonomia figurava a patrimonialidade como um valor fundante. Nas palavras das autoras Thamis Dalsenter e Maria Celina Bodin de Moraes,

Fundada no ideal liberal burguês, a concepção tradicional de autonomia privada funcionava como instituto capaz de garantir juridicamente um sistema econômico de circulação de bens e acumulação de riquezas a salvo das ingerências estatais. A autonomia operava por meio da dicotomia entre o direito público- garantia de uma administração que operava sob reserva de intervenção- e o direito privado- sistema em que "a liberdade do sujeito consistiria juridicamente em reconhecer à sua vontade o poder de regular situações jurídicas especialmente patrimoniais: ela se torna liberdade econômica que postula a economia de mercado e a livre concorrência' (PERLINGIERI, 2008, p. 339). ${ }^{1}$

A discrepância entre o âmbito público e o privado, percebe-se, é enraizada segundo esta configuração do ordenamento jurídico. Aqui, a autonomia privada encontra-se adstrita à sua dimensão patrimonial, teorizada a partir de um indivíduo ideal e modelar, pré-político, inteiramente capaz de

\footnotetext{
${ }^{1}$ BODIN DE MORAES, Maria Celina; DALSENTER, Thamis. A autonomia existencial nos atos de disposição do próprio corpo. Revista Pensar. Fortaleza, n. 3, set./dez. 2014, p. 785
} 
realizar negócios jurídicos e interessado em assegurar sua liberdade negocial. A liberdade neste momento é elaborada juntamente a um ideal de igualdade formal, tomada por seu viés patrimonial e associada a atividade econômica do sujeito, útil ao universo jurídico na medida em que movimenta um modelo de produção capitalista. A liberdade, desta forma, é ligada

(...) Não à ideia de pessoa concretamente identificada, mas tão somente à construção abstrata capaz de definir a todos como sujeitos de direito, e, por conseguinte, formalmente livres e igualmente possuidores de direitos e deveres. Esse quadro jurídico desprezou a pessoa em sua essência, assegurando somente a sua dimensão externa, os atributos necessários para o exercício de um papel socialmente previamente definido. Assim, a personalidade jurídica buscava qualificar o sujeito de acordo com as categorias jurídicas que legitimavam a capacidade e a vontade. ${ }^{2}$

Ainda de acordo com Bodin de Morais e Dalsenter, tal conformação jurídica culminou em uma espécie de hiperindividualismo, modelo segundo o qual os sujeitos, supostamente livres e iguais a priori, tornaram-se incapazes de criar laços de solidariedade e reciprocidade uns com os outros, limitando-se à execução da autonomia da vontade como uma espécie de "algoz da emancipação subjetiva"3, quase que em uma postura predatória, operando assim a manutenção de uma organização social estruturada de acordo com os ditames da ordem econômica.

No plano jurídico nacional, o Código Civil de 1916 acabou por refletir este paradigma liberal clássico, regulando em suas disposições majoritariamente aquelas relações jurídicas concebidas na esfera contratual, em especial no que tange ao direito da propriedade privada, dando corpo ao denominado "individualismo possessivo", termo cunhado para a noção de que o sujeito de direito é concebido como tal levando em conta a sua faceta patrimonial; sua humanidade vinculada a capacidade de exercer sua vontade em relações contratuais com outros indivíduos.

\footnotetext{
${ }^{2}$ BODIN DE MORAES, Maria Celina; DALSENTER, Thamis. Op. Cit., p. 789.

${ }^{3}$ Ibid. p. 787.

${ }^{4}$ MACPHERSON apud BODIN DE MORAES, Maria Celina; DALSENTER, Thamis. Op. Cit., p. 792.
} 
Nesse sentido, vale destacar a influência da obra de John Stuart Mill, pensador do século XIX, e sua contribuição teórica tanto neste primeiro cenário liberal burguês quanto no paradigma neoliberal do século seguinte. Mill tem como núcleo de sua tese o indivíduo abstrato e ideal, portador de liberdade e direitos, e não o Estado em sua atribuição de proteção ${ }^{5}$. Naquela considerada sua maior obra, "Sobre a Liberdade", Milll dispõe que

(...) O único fim para o qual a humanidade está autorizada, individual ou coletivamente, a interferir na liberdade de ação de qualquer fração de seu número é a auto-proteção. $\mathrm{O}$ único propósito para o qual o poder pode ser legitimamente exercido sobre qualquer membro de uma comunidade civilizada e contra a sua vontade é o de evitar danos aos demais. O seu bem próprio, seja ele físico ou moral, não é uma justificativa suficiente. Ele não pode ser legitimamente compelido a fazer ou abster-se de fazer algo porque será melhor para ele assim, porque isto o fará mais feliz, porque, segundo a opinião dos demais, seria prudente, ou mesmo certo, assim fazer. Estas são boas razões para admoestá-lo, ou para discutir com ele, ou persuadi-lo, ou rogar-lhe, mas não para compeli-lo ou para infligir-lhe qualquer dano caso ele proceda diferente. Para que isto se justifique, a conduta da qual é desejável dissuadi-lo deve ter a intenção de provocar danos a alguém mais. A única parte da conduta de alguém pela qual este é responsável perante a sociedade é aquela que diz respeito aos demais. Naquilo que concerne meramente a si mesmo, a sua independência, é, de direito, absoluta. Sobre si mesmo, sobre seu próprio corpo e mente, o indivíduo é soberano. ${ }^{6}$

O utilitarismo presente na obra de Mill consubstancia a noção de que a liberdade é a prerrogativa de "perseguir o nosso próprio bem à nossa própria maneira"7, compreendendo nesse sentido a liberdade de consciência, de expressão, de sentimento e de pensamento. A ação do indivíduo deve ser autodeterminada, ter em si mesmo sua própria referência, obrigatoriamente exonerada da submissão à vontade dos demais.

No centro do liberalismo clássico, portanto, firma-se a ideia fundamental de que o indivíduo deve agir da forma que bem entender, segundo suas crenças e valores próprios, devendo apenas ser refreado no caso

\footnotetext{
${ }^{5}$ RODRIGUES, Rafaela Araújo. Autonomia da Mulher e a Violência Doméstica: análise da Ação Direta de Inconstitucionalidade $\mathrm{n}^{\mathrm{o}} 4.424 \mathrm{sob}$ as perspectivas feministas da autonomia. Rio de Janeiro. 2014. Dissertação (Mestrado em Direito) - Programa de Pós-Graduação em Direito do Departamento de Direito da PUC-Rio, p. 17.

${ }^{6}$ MILL, Stuart. Sobre a Liberdade. In: WEFFORT, Francisco C. (Org). Os Clássicos da Política. $10^{\mathrm{a}}$ ed.. São Paulo: Editora Ática. 2001, p. 282.

${ }^{7}$ Ibid. p. 283.
} 
em que causar danos aos demais, somente nesta hipótese sendo requisitada a autorização da comunidade e do Estado para sua atuação.

Mill compreende que tal liberdade de atuação, eximida de interferências, levaria a uma estável vida democrática, participação política e autogoverno coletivo ${ }^{8}$. Para o autor, a liberdade é direito fundamental, e a capacidade de agir livremente de cada indivíduo seria capaz de gerar uma sociedade melhor organizada; a soberania sobre si, sobre a mente e sobre o corpo traria tanto ao indivíduo quanto à humanidade uma vantagem intrínseca.

Por este eixo de entendimento, a autonomia seria plenamente exercida a partir da eliminação de elementos de coerção e subjugação do indivíduo. A autonomia legítima é alcançada uma vez que essa eliminação é concretizada. Desta forma, fixa-se como responsabilidade política primária um ajuste ideal entre a liberdade individual e o controle social, capaz de impedir que a ação de uns prejudique a possibilidade de que outros definam como desejariam viver e procurem viver de acordo com esta presunção.

Torna-se evidente que os pressupostos do liberalismo moderno, brevemente dissertados acima e espelhados no século $\mathrm{XX}$ em sua reconfiguração contemporânea, foram responsáveis por essa noção elementar de oposição Estado-indivíduo, segundo a qual quanto maior o poder de interferência do Estado, mais ameaçado o direito fundamental à liberdade do indivíduo. Estado e sujeito, portanto, encontram-se em pólos diametralmente opostos; na medida em que um avança, o outro necessariamente recua.

Sob estes pilares é constituída a noção basilar de autonomia privada, compreendida como autodeterminação, autorregulamentação e poder da vontade. A esfera privada, segundo este entendimento primordial, deveria ser o local de aplicação dessa autonomia, vivenciada sem tolhimentos e com excepcionais vedações do Estado. A formulação da liberdade negativa é, no sistema filosófico liberal, colocada em evidência, tratando-se daquela zona de afastamento de intervenção alheia. A esfera pública, por outro lado, trata-

\footnotetext{
${ }^{8}$ MILL, Stuart. Op. Cit., p. 284.
} 
se do local produtivo de trabalho, aquele em cujas interações poderiam ser amplamente vigiadas pelo Estado.

O pensamento liberal contemporâneo invoca o núcleo espesso dos princípios emanados por Stuart Mill em um cenário histórico-político profundamente modificado, proclamando pela sua aplicação em uma sociedade plural e de orientação mercantil neoliberal. Gisele Cittadino contextualiza a produção de Ronald Dworkin e John Rawls, autores-expoente dessa vertente, na segunda metade do século $\mathrm{XX}$, tempos de queda do autoritarismo comunista no Leste europeu e restituição da ordem democrática em países latino-americanos que sofreram golpes militares. Segundo a autora, o tão anunciado "triunfo" da democracia liberal e o fim da utopia igualitária, associados ao trauma das constantes violações de direitos humanos, trouxeram novamente para o centro de debate a interseção entre ética, direito e política.

É neste contexto histórico complexo, em que regionalismos dos mais variados gêneros convivem com pretensões universalistas, sejam econômicas, sejam democráticas, que podemos assistir a um renascimento da filosofia política, que centra-se nas relações entre ética, direito e política e cuja principal marca é um indiscutível compromisso com os ideais democráticos. A filosofia política parece ter encontrado a certeza de que já não nos é possível sobreviver, face a esta conjuntura histórica, fora de algum padrão de eticidade e justiça. ${ }^{9}$

Afirma a autora que, nesta nova remissão jurídica ao universo da ética, já não é mais cabível qualquer referência a um indivíduo abstrato e ideal, como o faz Stuart Mill. "O indivíduo racional solitário está morto" ${ }^{10}$, constata Cittadino, e a partir disto as abstrações liberais contemporâneas caminham necessariamente pela via da intersubjetividade, ou seja, através de uma perspectiva relacional em uma sociedade plural, permeada de diferentes valores culturais e percepções de mundo, bem como noções de vida digna diversas. A intersubjetividade é, portanto, marco de referência da ética e política neste cenário de reconstrução democrática.

\footnotetext{
${ }^{9}$ CITTADINO, Gisele. Pluralismo, direito e justiça distributiva: elementos da filosofia constitucional contemporânea. $4^{a}$ ed.. Rio de Janeiro: Lumen Juris, 2009, p. 76.

${ }^{10}$ Ibid. p. 76.
} 
Gisele Cittadino aduz que grande parte dos pensadores liberais contemporâneos se voltam contra o perfeccionismo, o paternalismo e sua dimensão moralista ${ }^{11}$, compreendendo o indivíduo como aquele capaz de atuar segundo suas próprias noções de vida digna ${ }^{12}$. O sujeito autodeterminado, segundos Rawls e Dworkin, é aquele apto a estabelecer suas próprias preferências subjetivas e, assim, proferir escolhas autônomas.

John Rawls pressupõe que há uma "ideia intuitiva básica implícita na cultura pública das democracias que descreve a sociedade como um sistema equitativo de cooperação entre pessoas livres e iguais"13. Para Rawls, a ideia de uma "sociedade bem ordenada" presume a existência anterior de uma "concepção política de justiça" que a sustenta, esta independente de qualquer doutrina moral, filosófica ou religiosa. Segundo o critério rawlsiano, inspirado nas dissertações de Mill, uma "liberdade fundamental só pode ser limitada ou negada em nome de outra ou de outras liberdades fundamentais"14.

O autor também postula que os cidadãos são pessoa livres e iguais; livres porquanto possuem atributos racionais, como a capacidade de raciocinar, e morais, como a capacidade de ter um senso norteador de justiça e de adotar uma concepção de bem. Também seriam iguais na medida em que possuem tais faculdades em grau necessário para se tornarem cooperativos nesta sociedade.

Ronald Dworkin, por sua vez, confere a autonomia da vontade papel central em sua obra. O liberalismo dworkiano congrega em seu âmago o pressuposto de que uma comunidade política deve tratar seus membros como

\footnotetext{
${ }^{11}$ CITTADINO, Gisele. Pluralismo, direito e justiça distributiva: elementos da filosofia constitucional contemporânea. $4^{\mathrm{a}}$ ed.. Rio de Janeiro: Lumen Juris, 2009, p. 79.

${ }^{12}$ RODRIGUES, Rafaela Araújo. Autonomia da Mulher e a Violência Doméstica: análise da Ação Direta de Inconstitucionalidade $\mathrm{n}^{\circ} 4.424 \mathrm{sob}$ as perspectivas feministas da autonomia. Rio de Janeiro. 2014. Dissertação (Mestrado em Direito) - Programa de Pós-Graduação em Direito do Departamento de Direito da PUC-Rio, p. 19.

${ }^{13}$ CITTADINO, Gisele. Op. Cit., p. 80.

${ }^{14}$ RAWLS, John apud SILVA, Julio César Casarin Barroso Silva. Liberdade de expressão, pornografia e igualdade de gênero. Revista Estudos Feministas. Florianópolis, n. 1, p. 143-165, jan./abr. 2013. Disponível em: http://www.scielo.br/scielo.php?script=sci_arttext\&pid=S0104026X2013000100008\#back22. Acesso em 07 jun. 2017.
} 
cidadãos que possuem um igual status político e moral, e o Estado liberal deve se abster de qualquer concepção acerca da vida digna ${ }^{15}$. A postura adequada ao Estado é a de firmar um compromisso com a neutralidade perante as diferentes concepções de bem do sujeito, elevando todos os seus membros a um mesmo patamar de consideração na comunidade política. Assim é gerada a igualdade e, consequente e reciprocamente, garantida a liberdade. Cittadino reitera que:

Esta igualdade, que pressupõe os indivíduos como agentes morais independentes, exige que direitos fundamenteis lhes sejam atribuídos, para que tenham a oportunidade de influenciar a vida política, realizar os seus projetos pessoais e assumir as responsabilidades pelas decisões que sua autonomia lhes assegura.

Assim sendo, verifica-se, no centro do debate liberal contemporâneo, um ideal de autonomia privada alicerçado na elaboração de normas e instituições que possam garantir igual disposição entre indivíduos para estabelecer e buscar suas concepções particulares de bem e vida digna. Desta forma poderá o indivíduo proferir livre e intimamente a escolha de como melhor governar sua vida, definindo seu próprio destino sem coerções ou coibições estatais de fundamento moral, reservada a extraordinária hipótese em que a eleição por determinado modo de viver resulte na impossibilidade outro projeto pessoal de vida, igualmente legítimo, de outrem.

\subsection{Introdução à crítica feminista: a presença da opressão de gênero na oposição público-privado}

Como dissertado na breve síntese das páginas anteriores, o paradigma liberal compreende a autonomia como faculdade de atuação do sujeito em consonância à sua vontade íntima e singular. Em uma sociedade pluralista, com concepções de vida digna multiplicadas, o Estado deve garantir condições para o pleno exercício dessa autonomia, nivelando os indivíduos

15 CITTADINO, Gisele. Pluralismo, direito e justiça distributiva: elementos da filosofia constitucional contemporânea. $4^{\mathrm{a}}$ ed.. Rio de Janeiro: Lumen Juris, 2009, p. 81 
ao mesmo grau de paridade social para que possam, assim, como iguais, exercerem suas escolhas livremente.

Sob esta ótica, as delimitações entre o domínio público e privado se acirram. O âmbito público é regido por princípios universais, pela razão e impessoalidade, ao passo que a esfera particular acolheria as relações de caráter íntimo e pessoal ${ }^{16}$. Se na primeira os indivíduos são definidos como manifestações da humanidade ou da cidadania comuns a todos, na segunda se apresentam em suas individualidades concretas e particulares. A esfera privada torna-se, assim, asilo inviolável da vontade do sujeito, abarcando em si atos e relações que não poderão ser tangíveis pelo Estado, vez que se trata de campo reservado à livre expressão da singularidade individual.

Do que é composto, no entanto, esse território particular impenetrável? Quem são os personagens que o povoam, à sombra do Estado? Quais são as interações que restam obscurecidas por essa imperceptibilidade da esfera privada? Quando a dualidade entre a esfera pública e a privada é questionada, a própria noção de política é redefinida.

Os movimentos feministas da chamada segunda onda, originados na década de 1960, já interrogavam com o mote "o pessoal é político" 17 a quem serviria este forte delineamento entre as duas zonas, buscando questionar o critério de delimitação de suas fronteiras e criticar a determinação prévia de papéis exercidos por homens e mulheres em cada uma delas. A dicotomia

\footnotetext{
${ }^{16}$ BIROLI, Flavia; MIGUEL, Luis Felipe. Teoria política feminista: textos centrais. $2^{2}$ ed.. São Paulo: Editora Horizonte, 2013, p. 15.

${ }^{17} \mathrm{O}$ artigo "The Personal is Political", de Carol Hanisch, foi publicado em Notes from the Second Year: Women's Liberation no ano de 1969. Embora o slogan não comporte em si mesmo um significado auto-evidente, tendo sido articulado por diferentes vias argumentativas, o artigo reflete sobre a possibilidade de confusão entre os temas tradicionalmente pessoais e os tópicos relevantes a discussão política, como, no caso, as temáticas discutidas por mulheres em terapia. Carol Hanish atentou que: "I believe at this point, and maybe for a long time to come, that these analytical sessions are a form of political action. I do not go to these sessions because I need or want to talk about my "personal problems." In fact, I would rather not. As a movement woman, I've been pressured to be strong, selfless, other-oriented, sacrificing, and in general pretty much in control of my own life. To admit to the problems in my life is to be deemed weak. So I want to be a strong woman, in movement terms, and not admit I have any real problems that I can't find a personal solution to (except those directly related to the capitalist system). It is at this point a political action to tell it like it is, to say what I really believe about my life instead of what I've always been told to say". Disponível em: http://www.carolhanisch.org/CHwritings/PIP.html. Acesso em 23/04/2017.
} 
público-privado alimenta uma compreensão restrita da política, que em nome da universalidade da esfera pública define uma série de tópicos e experiências como privados e, como tal, não políticos. Trata-se de uma uma forma de isolar a política das relações de poder na vida cotidiana da mulher ${ }^{18}$.

O grande impacto da segunda onda, pode-se dizer, foi revelar o caráter ideológico presente por trás das formulações liberais sobre o privado e o público $^{19}$. Nas palavras de Luis Felipe Miguel e Flavia Biroli,

Características atribuídas como naturais às mulheres, como a dedicação prioritária a vida doméstica e aos familiares, colaboram para que a domesticidade feminina fosse vista como natural traço natural e distintivo. (...) Nesse quadro, a preservação da esfera privada relativamente à intervenção do Estado e mesmo às normas e valores vigentes na esfera pública significou, em larga medida, a preservação de relações de autoridade que limitaram a autonomia das mulheres. (...) Em nome da preservação da esfera privada, garantias aos direitos dos indivíduos na família foram menores do que as garantias publicamente estabelecidas. ${ }^{20}$

A esfera privada, sob a perspectiva crítica feminista, é um também um espaço de reprodução de assimetrias e agressões da ordem da opressão de gênero. As relações pactuadas entre indivíduos, ainda formalmente livres e iguais como no contrato de casamento, podem acarretar na submissão e na incapacidade autodeterminação das mulheres. Afirma-se que as circunstâncias tidas como de caráter pessoal e íntimas ao sujeito são legalmente percebidas através de articulações públicas. Leis concernentes ao estupro e ao aborto, bem como o status jurídico antigamente conferido à "esposa" e a regulação da disposição do próprio corpo no âmbito da sexualidade são normativas formuladas no bojo da esfera pública, logo consequentemente deliberadas em sua maioria por homens. Diante este quadro, fez-se necessário o deslocamento para o centro de sua agenda política feminista tópicos como a disparidade salarial entre gêneros, as violências

\footnotetext{
${ }^{18}$ BIROLI, Flavia; MIGUEL, Luis Felipe. Teoria política feminista: textos centrais. $2^{\mathrm{a}}$ ed.. São Paulo: Editora Horizonte, 2013, p. 14.

${ }^{19}$ PATEMAN, Carole. Críticas feministas à dicotomia público/privado. In: BIROLI, Flavia; MIGUEL, Luis Felipe (Org). Teoria política feminista: textos centrais. São Paulo: Editora Horizonte, 2013, p. 56.

${ }^{20}$ BIROLI, Flavia; MIGUEL, Luis Felipe. Op. Cit., p. 14.
} 
sofridas no ambiente doméstico, os direitos reprodutivos da mulher, a maternidade e a sexualidade ${ }^{21}$. Temas tradicionalmente- e cada um à sua maneira- designados ao âmbito de atuação particular do indivíduo.

A crítica feminista neste momento, embora apresente ramificações teóricas nos mais diversos sentidos ${ }^{22}$, parte de uma mesma ruptura básica desta concepção liberal cristalizada sobre dualidade público versus privado. É o mundo real, atravessado por desigualdades, que define possibilidades e organiza distintamente o acesso a recursos entre homens e mulheres; as medidas de garantia da liberdade não podem avaliar o sujeito em sua caracterização abstrata. Em diferentes camadas, a dicotomia entre os dois âmbitos explicita as características atribuídas a cada gênero e seu devido papel na respectiva esfera de atuação ${ }^{23}$.

Para fins de ilustrar a postura da crítica feminista quanto a este aspecto, vale citar a renomeada obra de Carole Pateman, "O Contrato Sexual". Neste trabalho, enuncia-se que a teoria do contrato social, o clássico acordo originário da sociedade civil ocidental, envolve uma dimensão suprimida: a sexual. Segundo a autora, o contrato original nasce a partir de uma ordem patriarcal, e a noção de liberdade individual apregoada nas suas sociedades jamais poderia ser considerada universal, tendo em vista que é um atributo masculino e depende do direito patriarcal ${ }^{24}$. O contrato sexual é o

\footnotetext{
${ }^{21}$ RODRIGUES, Rafaela Araújo. Autonomia da Mulher e a Violência Doméstica: análise da Ação Direta de Inconstitucionalidade $\mathrm{n}^{\mathrm{o}} 4.424 \mathrm{sob}$ as perspectivas feministas da autonomia. Rio de Janeiro. 2014. Dissertação (Mestrado em Direito) - Programa de Pós-Graduação em Direito do Departamento de Direito da PUC-Rio, p. 16.

${ }^{22}$ As divergências teóricas aqui também dizem respeito a própria substância do conceito de público e privado nessas subdivisões.

23 "Na consciência popular (e acadêmica), a dualidade entre feminino e masculino costuma servir para sintetizar ou representar a série (ou o círculo) de separações e oposições liberais: feminino ounatureza, pessoal, emocional, amor, privado, intuição, moralidade, atribuição, particular, sujeição; masculino ou- cultura, político, razão, justiça, público, filosofia, poder, êxito, universal, liberdade. A mais fundamental e geral dessas posições associa as mulheres à natureza e os homens à cultura, $\mathrm{e}$ várias feministas contemporâneas definiram suas críticas nesses termos.” PATEMAN, Carole. Críticas feministas à dicotomia público/privado. In: BIROLI, Flavia; MIGUEL, Luis Felipe (Org). Teoria política feminista: textos centrais. São Paulo: Editora Horizonte, 2013. p. 62.

24 "O termo 'ideologia' é apropriado neste caso porque a profunda a ambiguidade da concepção liberal de privado e público obscurece e mistifica a realidade social que ajuda a construir. (...) Eles não reconhecem que o 'liberalismo' é liberalismo patriarcal e que a separação e a oposição das esferas pública e privada é uma oposição desigual entre homens e mulheres, Portanto, aceitam o discurso sobre 'indivíduos' na teoria liberal como ele é apresentado, embora, a partir do período em
} 
meio pelo qual homens convertem seu poder sobre as mulheres na segurança de um direito patriarcal civil. Nas palavras da autora, "o contrato cria o direito político dos homens sobre as mulheres, e também sexual no sentido do estabelecimento de acesso sistemático dos homens aos corpos das mulheres" 25 .

Em um apanhado analítico dos principais autores do contrato social, Pateman reforça que, pelo entendimento do paradigma teórico liberal, a história do contrato social é contada como um relato da constituição da esfera pública em oposição à privada, esta tida como politicamente desimportante. Os indivíduos que firmam o contrato social são livres e iguais, capazes de exercer o poder político e plenamente estabelecer atos negociais.

Pateman pontua que o casamento e o contrato matrimonial, bem como as relações estabelecidas no ambiente doméstico em geral- entre elas as sexuais- por pertencerem comumente a esfera particular de atuação do indivíduo foram historicamente consideradas questões politicamente irrelevantes ${ }^{26}$. Entretanto, sublinha Pateman, também nessa ceara experimenta-se a opressão contra a mulher; violência, portanto, ofuscada à atenção estatal. Por conseguinte, a mulher, em sua condição de esposa, é excluída da vida pública, do consentimento e das convenções, inviabilizada ao pertencer forçosa e exclusivamente a vida privada. Do contrato original, por conseguinte, se origina a "lei do direito sexual masculino", meio pelo qual se constitui o patriarcado moderno.

A teoria feminista finca seu ideário no pressuposto de que estruturas hierárquicas de gênero que atravessam toda a sociedade, organizando cada esfera da vida social, desde o seio da família até o arranjo do mercado de trabalho. Segundo Pateman,

que os teóricos do contrato social atacaram os patriarcalistas, os teóricos liberais tenham excluído as mulheres do âmbito de seus argumentos aparentemente universais.” Ibid., p. 56-57.

${ }^{25}$ PATEMAN, Carole. O contrato sexual. São Paulo: Ed. Paz e Terra.1988, p. 17.

${ }^{26}$ Ibid., p. 18. 
As feministas argumentam que o liberalismo é estruturado por relações patriarcais, bem como de classe, e que a dicotomia entre o privado e o público obscurece a submissão das mulheres aos homens dentro de uma ordem aparentemente universal, igualitária e individualista. ${ }^{27}$

As dimensões público e privado, constata-se, são apenas formalmente apartadas, vez que tratam-se em verdade de esferas absolutamente interligadas por uma rede de estruturação patriarcal da sociedade. Sendo assim, a esfera doméstica e suas temáticas encontram-se no coração da sociedade civil, e não desprendida dela. O feminismo foi o grande responsável pelo embaralhar dos conceitos de público e privado, político e "apolítico", tão fixamente definitos e discriminados pelo paradigma liberal.

O conceito de divisão sexual do trabalho ajuda a visualizar de que forma a desigualdade entre homens e mulheres problematiza as configurações previamente estabelecidas entre público e privado. Trata-se de um dos motores da definição de posições distintas para os dois gêneros ${ }^{28}$. A divisão é perceptível pela destinação aferida aos homens da esfera produtiva no mercado e das mulheres à esfera privada, fundando suas divisórias na hierarquia e na separação ${ }^{29}$.

O princípio da separação é responsável pela determinação do que é o trabalho tipicamente feminino e o tipicamente masculino- as mulheres destinadas ao trabalho reprodutivo, invisível e doméstico e os homens, ao trabalho remunerado realizado dentro da esfera pública. O princípio da hierarquia, por sua vez, confere maior valorização ao trabalho do homem que o da mulher; seja a nível simbólico, na apreciação da importância do trabalho do homem em detrimento ao da mulher, este tido como subsidiário, fútil ou

\footnotetext{
${ }^{27}$ PATEMAN, Carole. O contrato sexual. São Paulo: Ed. Paz e Terra.1988, p. 57.

${ }^{28}$ BIROLI, Flavia; MIGUEL, Luis Felipe. Teoria política feminista: textos centrais. $2^{\mathrm{a}}$ ed.. São Paulo: Editora Horizonte, 2013, p. 35.

29 "É claro que as mulheres nunca estiveram completamente excluídas da vida pública, mas a forma como elas são incluídas está baseada, tão firmemente quanto a sua posição na esfera doméstica, em crenças e práticas patriarcais." PATEMAN, Carole. Críticas feministas à dicotomia público/privado. In: BIROLI, Flavia; MIGUEL, Luis Felipe (Org). Teoria política feminista: textos centrais. São Paulo: Editora Horizonte, 2013. p. 71.
} 
menos esforçado, ou a nível financeiro, com a maior remuneração de homens do que mulheres no mercado de trabalho ${ }^{30}$.

\subsection{A problemática na formulação de preferências subjetivas}

O sub-capítulo anterior buscou elucidar, ainda que a nível introdutório, de que forma a crítica feminista questiona, pela primeira vez, a ordem de divisão categórica entre homens e mulheres dentro das esferas público e privado, previamente estabelecidas pela dogmática liberal de separação entre os dois.

Discorreu-se, com base no argumento de Carole Pateman, como as mulheres foram excluídas de uma vida pública, iminentemente política, e inviabilizadas pelo Estado por serem reiteradamente associadas a tarefas, lugares e questões da ordem da vida privada, âmbito supostamente esvaziado de conteúdo político. $\mathrm{O}$ feminismo, neste momento, pretendeu confundir as noções fixadas de público e privado, demonstrando a hierarquização de gênero presente na gênese dessas distinções, bem como a conexão inerente ao âmbito público e privado, ambos atravessados por uma mesma lógica patriarcal.

Contra essa tese, a preservação da privacidade foi sistematicamente alegada em uma tentativa de promover a manutenção do patriarcado,

\footnotetext{
${ }^{30}$ Carole Pateman escreve no momento em que mulheres paulatinamente começavam a ocupar espaços no mercado de trabalho tipicamente associados aos homens. Segundo Pateman, "uma grande quantidade de mulheres da classe trabalhadora sempre teve de entrar no mundo público do emprego remunerado para garantir a sobrevivência de suas famílias, e uma das características mais marcantes do capitalismo pós-guerra foi o emprego de um número sempre crescente de mulheres casadas" (PATEMAN, Carole. O contrato sexual. São Paulo: Ed. Paz e Terra.1988, p. 72).No entanto, nota a autora que, embora fosse visível a escalada ascendente no número de mulheres no mercado de trabalho, as área profissionais as quais eram destinadas possuíam predominantemente baixo status, empregos mal-remunerados e quase jamais configuravam cargos de chefia. Vale dizer, portanto, que a presença das mulheres no mercado de trabalho ainda assim era capaz de salientar a perpetuidade da ordem patriarcal existente na divisão sexual do trabalho.

Faz-se pertinente atualizar a discussão, pontuando que, em recente pesquisa realizada pelo Instituto Brasileiro de Geografia e Estatística (IBGE), realizada no ano de 2012, o panorama comparativo da mulher no mercado profissional com relação ao homem demonstrou que os locais de trabalho onde as mulheres estão inseridas continuam apresentando menor remuneração, baixo status e uma disparidade salarial de quase $30 \%$.
} 
especialmente dentro de um ideário liberal, que, como anunciado anteriormente, visava conferir ao domínio privado absoluta ressalva de interferência estatal. Desta forma, a privacidade é invocada como pretexto velado para a proteção do domínio masculino sobre a mulher.

A divisão sexual do trabalho é alegada por Pateman e possui relação direta com a socialização diferenciada entre gêneros, com a construção diferenciada de horizontes de possibilidade para homens e mulheres, desde a sua infância. Nascer homem ou mulher, desta forma, possui impacto direto sobre as articulações no exercício da autonomia.

Se a própria discrição entre o que é da ordem pública e do âmbito pessoal congrega em si mesmo um fundamento patriarcal e opressor, também as relações íntimas e as escolhas pessoais poderão espelhar esta lógica desigual entre homens e mulheres. A segunda onda feminista promove um movimento de politização daquilo tradicionalmente entendido enquanto "pessoal": o afeto, o corpo, a sexualidade. Discute-se os limites e os sentidos da regulação da esfera privada e o valor da privacidade. Nesse contexto pode emergir o debate sobre pornografia.

Aqui pretende-se perfurar outra camada, sensivelmente mais profunda, na discussão sobre a liberdade da mulher, com o objetivo de promover o salto necessário para adentrar a discussão do tema central deste trabalho. O debate sobre autonomia é transferido para outra ceara de discussão. As preferências "adaptativas" ou "aprendidas" são, neste eixo de reflexão, um problema nuclear para a análise da reprodução de desigualdades de gênero, levando a discussões que superam a oposição entre autonomia e coerção em direção a compressões mais complexas e matizadas do processos sociais que levam a restrições diferenciadas da autonomia ${ }^{31}$.

Busca-se averiguar como a desigualdade de gênero pode influenciar nas próprias concepções de vida intimamente concebida por mulheres, em

\footnotetext{
${ }^{31}$ BIROLI, Flavia; MIGUEL, Luis Felipe. Teoria política feminista: textos centrais. $2^{\text {a }}$ ed.. São Paulo: Editora Horizonte, 2013, p. 35.
} 
suas preferências subjetivas, no exercício de sua autonomia em si. Nesse sentido,

As análises (feministas) mantém o valor da autonomia, mas procuram desvinculálo de noções correntes da responsabilidade individual. O indivíduo autônomo não é aquele que determina inteiramente sua vida; esta é uma abstração que colabora para valorizar quem está em posição vantajosa em determinados contextos e arranjos institucionais, ao mesmo tempo em que caracteriza como desviastes aqueles que não "dão conta" de si. Em outras palavras, as formas sociais de produção da vulnerabilidade são enfocadas, em vez de presumir que as ações individuais poderiam ser explicadas como desdobramentos de ações responsáveis ou falhas que levariam à autonomia e independência (no primeiro caso) e à dependência e inaptidão para cuidar de si e dos seus (no segundo caso). ${ }^{32}$

Flavia Biroli, em "Agentes Imperfeitas: contribuições do feminismo para a análise da relação entre autonomia, preferências e democracia", retoma a relevância das noções de distinção entre as escolhas de vida estabelecidas pelo crivo alheio em detrimento aquelas estabelecidas pelos próprios indivíduos presentes no liberalismo contemporâneo de Dworkin e Rawls. Segundo a autora, essa distinção é necessariamente embaçada se a considerarmos do ponto da vista da crítica feminista. Isto porque:

As hierarquias de gênero produzem preferências e identidades que reafirmam a posição de subordinação e vulnerabilidade relativa das mulheres: essa á uma das bases para a crítica à consideração das preferências já produzidas como um ponto de partida para as análises e a formulação de políticas. Mas há uma série de complicações quando, desfeita a clareza da distinção entre formas de vida impostas e formas de vida escolhidas, consideramos a posição do indivíduo em relação a 'suas' preferências e escolhas. O reconhecimento da complexidade na produção das preferências (...) não resolve o problema do estatuto político e moral conferido aos indivíduos em contextos nos quais há opressão- e internalização de valores e práticas que permitem que essa opressão se mantenha é uma opção que pode ser considerada. ${ }^{33}$

Para dar início ao debate sobre pornografia, o problema, portanto, deve ultrapassar as manifestações exteriores das relações de poder entre homens e mulheres, tratando-se de um dilema que alcança o universo interior

\footnotetext{
${ }^{32}$ BIROLI, Flavia; MIGUEL, Luis Felipe. Teoria política feminista: textos centrais. Op. Cit., p. 35

${ }^{33}$ BIROLI, Flavia. Agentes imperfeitas: contribuições do feminismo para a análise da relação entre autonomia, preferências e democracia. Revista Brasileira de Ciência Política. Brasília, n. 9, p. 7-38, set./dez. 2012, p. 12.
} 
da mulher. Trata-se de uma transformação teórica. Pergunta-se: o que é próprio ao indivíduo, e deveria ser garantido para que se proteja a integridade individual? O que, por outro lado, lhe é imposto ou é efeito da impossibilidade de escolher ou refletir sobre suas escolhas?

Algumas autoras entendem que, a partir da internalização de relações de poder, as escolhas e preferências de mulheres socializadas em contextos de opressão podem ser modeladas com base em parâmetros nocivos para si mesmas. Faz parte das abordagens críticas aos mecanismos de reprodução e desigualdade de gênero a consideração de que padrões opressivos de socialização e relações hierárquicas de poder podem constituir impedimentos à autonomia da mulher, na medida em que a (re)inserem em ciclos de vulnerabilidade, naturalizando posições desvantajosa, bem como práticas e identidades que as mantêm.

Trata-se dos posicionamentos firmados por Catharine MacKinnon e Andrea Dworkin, doutrinadoras feministas comprometidas com o debate sobre pornografia. Faz-se necessário, para o avanço deste estudo, ingressar em uma nova instância do debate com relação a gênero, autonomia e direito ao corpo. 


\section{Ao centro do debate sobre pornografia}

\subsection{Contextualizando o ativismo feminista anti-pornografia}

O fim dos anos 70 consolidou um marco no ativismo norte-americano, anunciando uma curva na produção teórica feminista das décadas seguintes. Temas como a proteção de direitos reprodutivos e debates sobre pornografia e prostituição tomaram cada vez mais espaço dentro da luta pela emancipação de mulheres, priorizados em sua agenda política. Tal período, conhecido como a "era de ouro da pornografia" ${ }^{4}$, presenciou o boom nas produções de longa-metragens pornográficos nos cinemas comerciais e através do surgimento e distribuição do VHS.

A crescente popularização da pornografia- vale lembrar que o icônico filme Garganta Profunda foi produzido em 1972- despertou uma série de preocupações no movimento feminista, levando tanto a formação de grupos manifestamente anti-pornografia quanto pró-sexo e anti-censura. Em 1976 é criado o Women Against Violence in Pornography and Media (WAVPM), e em 1979 o Women Against Pornography (WAP). Na direção contrária, a vertente sex-positive clamava pelo direito a livre expressão sexual da mulher e reforçava a importância de assumir uma agência marginal dentro de uma cultura sexual patriarcal. O Samois, grupo composto por mulheres lésbicas sado-masoquistas, embora tenha durado apenas entre 1978 e 1983, foi de importância emblemática para a discussão sobre pornografia.

Entre as autoras anti-pornografia ${ }^{35}$, Andrea Dworkin e Catharine Mackinnon assumem posição central, tendo não apenas contribuído teoricamente para o tema mas também elaborado projetos de lei visando medidas estatais que coibissem a circulação de material pornográfico.

\footnotetext{
${ }^{35}$ A respeito da inserção do movimento anti-pornografia no feminismo, Raisa Duarte da Silva Ribeiro disserta que "o movimento feminista anti-pornografia engloba diversas ondas do feminismo, encontrando no feminismo de segunda geração ou no feminismo radical as vozes mais latentes e ecoantes." RIBEIRO, Raisa Duarte. Corporalidade e Pornografia: uma análise crítica à luz dos estudos de David Le Breton. Congresso Internacional Interdisciplinar em Sociais e Humanidades. Foz do Iguaçu, n. 4, 8 a 11 dez. 2015, p. 7.
} 
Autoras como Carol Vance e Gayle Rubin foram responsáveis pela produção da retórica anti-censura, entendendo que o feminismo deveria acrescentar as suas propostas a criação de uma nova teoria sobre a sexualidade ${ }^{36}$. Nessa mesma esteira crítica, entendeu-se que a abordagem de vitimização das mulheres, bem como sua condenação à "sexualidade masculina", levaria o feminismo a aliar-se politicamente a setores mais conservadores da sociedade. De fato, para fazer avançar as leis anti-pornografia, as autoras valeram-se de articulações com a direita estadunidense, com sua agenda moral retrógrada e totalmente ligada a grupos religiosos ${ }^{37}$.

Este trabalho, no entanto, será conduzido pelo entendimento antipornografia apresentado por Dworkin e MacKinnon, não avançando no estudo sobre a teoria prosex. A produção destas autoras servirá de base para este trabalho. Na linha do ativismo anti-pornografia, ambas compartilham a noção essencial de que a disseminação de conteúdo pornográfico e violência de gênero estão indissociavelmente conectadas. Raisa Duarte da Silva Ribeiro, professora e estudiosa das autoras, anuncia que o entendimento consubstanciado entre as representantes do movimento anti-pornografia é de que a pornografia exibe as mulheres como seres valorosos enquanto coisas, objetos sexuais desumanizados, destinados as servir à vontade masculina ${ }^{38}$.

Andrea Dworkin, em “Pornography: Men Possessing Women”, atenta para a raiz etimológica da palavra pornografia. Graphos, termo grego, representa todo tipo de escrito, gravura ou desenho. Porne ou porneia, por sua vez, representa prostituta. A porneia, todavia, não era qualquer prostituta; tratava-se daquela pertencente a camada mais rebaixada na prostituição, a mais vil, desprezível e desvalorizada prostituta, disponível a todos os homens

\footnotetext{
${ }^{36}$ SANTANA, Camilla Martins. Da pornografia à pornoteoria: desafios e reimaginações feministas. 2016. Brasília. Tese (Mestrado em Ciências Sociais) - Departamento de Sociologia da Universidade de Brasília, p. 71.

${ }^{37}$ BIROLI, Flavia; MIGUEL, Luis Felipe. Teoria política feminista: textos centrais. $2^{a}$ ed.. São Paulo: Editora Horizonte, 2013, p. 17.

${ }^{38}$ RIBEIRO, Raisa Duarte. Corporalidade e Pornografia: uma análise crítica à luz dos estudos de David Le Breton. Congresso Internacional Interdisciplinar em Sociais e Humanidades. Foz do Iguaçu, n. 4, 8 a 11 dez. 2015, p. 8.
} 
pelo preço mais baixo. A porneia era uma espécie de escrava sexual nos bordéis $^{39}$. Dworkin acredita que a única palavra na composição etimológica de pornografia que efetivamente sofreu alterações em seu significado na contemporaneidade foi graphos; de fato, os meios de representação gráfica do conteúdo pornográfico transformaram-se de incontáveis maneiras. A brutalidade contida no significado de porneia, por outro lado, permanece presente: para a autora, a pornografia segue exibindo mulheres como prostitutas vis, destinadas para servir ao prazer masculino, somente passíveis de existir em uma conjuntura de dominação masculina ${ }^{40}$.

MacKinnon entende a pornografia como fenômeno cultural difundido globalmente, considerada a maior forma de educação sexual em países ocidentais. É também por meio dela que homens iniciam a investigação do próprio corpo, assimilam seus desejos e, assim, podem vir a reproduzir comportamentos, sendo a subordinação e a violação da mulher o que eles aprendem a sexualizar ${ }^{41}$. Em razão do alcance prático destes malefícios da pornografia para a mulher, MacKinnon e Dworkin não se contiveram em posturas teóricas, tendo suas ideias excedido o formato academicista. É necessário reconhecer o caráter militante das ideias expressas pelas duas, que buscaram promover uma mudança prática na forma com que o material

\footnotetext{
39 "The word pornography, derived from the ancient Greek pome and graphos, means 'writing about whores'. Porne means whore, specifically and exclusively the lowest class of whore, which in ancient Greece was the brothel slut available to all male citizens. The porne was the cheapest (in the literal sense), least regarded, least protected of all women, including slaves. She was, simply and clearly and absolutely, a sexual slave. Graphos means 'writing, etching, or drawing'." DWORKIN, Andrea. Pornography: Men possessing women. Nova Iorque: G. P. Putnam's Sons. 1981.

40 "Contemporary pornography strictly and literally conforms to the world's root meaning: the graphic depiction of vile whores, or, in our language, sluts, cows (as in: sexual cattle, sexual chattel), cunts. The world has not changed its meaning and the genre is not misnamed. The only change in the meaning of the word is with respect to its second parte, graphos: now there are cameras- there is still pornography, film, video. The methods of graphic depiction have increased in number and in kind: the content is the same; the meaning is the same; the purpose is the same; the status of the women depicted is the same; the sexuality of the women depicted is the same; the value of the women depicted is the same. With technology advanced methods of graphic depiction, real women are required for the depiction as such to exist". Ibid.

41 "It's a massive and widespread cultural phenomenon. Pornography is the largest form of sex education we have in this country, it's how men learn their own bodies and their own responses. (...) The subordination of women is what they learn to sexualize." MACKINNON, Catharine. The Pornography Phenomenon. Disponível em https://www.youtube.com/watch?v=kdfPLJDmEIw. Acesso em 25/05/2017.
} 
pornográfico estava sendo produzido e encarado pelo Estado. Tratava-se de um movimento político pela igualdade civil. No ano de 1983, Dworkin e MacKinnon elaboraram dois textos normativos, as ordenações antipornografia das cidades de Mineápolis e Indianápolis, que visavam regular a circulação de material pornográfico através da restrição da "produção, venda, exibição e distribuição" de qualquer material enquadrado no conceito de pornografia. Nele, o conteúdo pornográfico é definido como a exibição gráfica da subjugação sexual da mulher, que através de comportamentos violentos e depreciativos é degradada ou abusada em sua integridade, de forma a endossar e naturalizar a violência de gênero ${ }^{42}$.

Na cidade de Mineápolis, o projeto de lei obteve aprovação pelo Legislativo, mas foi banido pelo prefeito com fundamento na violação da Primeira Emenda da Constituição norte-americana. Já em Indianápolis, o projeto adquiriu o status de lei, porém teve sua constitucionalidade negada pelo Sétimo Circuito de Apelações do Estado, em sentença redigida pelo juiz Frank Easterbrook ${ }^{43}$. Com a recusa da Suprema corte em analisar o caso, a decisão fez-se definitiva.

Nos próximos subcapítulos, pretende-se elucidar as premissas teóricas e jurídicas que levaram Dworkin e MacKinnon a redigir os projetos de lei, bem como apontar as represálias do Judiciário as teses elaboradas.

\footnotetext{
${ }^{42}$ RIBEIRO, Raisa Duarte. Corporalidade e Pornografia: uma análise crítica à luz dos estudos de David Le Breton. Congresso Internacional Interdisciplinar em Sociais e Humanidades. Foz do Iguaçu, n. 4,8 a 11 dez. 2015 , p. 8.

43 "Em 1985, essa lei foi considerada inconstitucional pelo Sétimo Circuito de Apelações, o qual, através do juiz Frank Easterbrook, rejeitou os argumentos da cidade. $\mathrm{O}$ argumento do juiz foi o de que a censura em questão representava uma censura com base no ponto de vista, coisa praticamente impossível de se justificar no sistema de expressão que vige nos Estados Unidos, de acordo com o qual um dos principais objetivos da Primeira Emenda é evitar censura desse tipo. Além disso, o juiz não deu maior importância à relação causal apontada pelas feministas entre pornografia e violência contra a mulher. Sem a questionar, Easterbrook afirmou que o ponto importante do sistema de liberdade de expressão é permitir ideias independentemente das consequências que elas venham a ter, porque, 'sob a Primeira Emenda, o governo deve deixar ao povo a avaliação das ideias'." SILVA, Julio César Casarin Barroso Silva. Liberdade de expressão, pornografia e igualdade de gênero. Revista Estudos Feministas. Florianópolis, n. 1, p. 143-165, jan./abr. 2013.
} 


\subsection{Desejo, poder e autonomia}

De onde parte a urgência de se regular a pornografia em MacKinnon e Dworkin? Na conferência "Desejo e Poder", realizada na universidade de Harvard em 1983, MacKinnon anuncia que a sexualidade é o processo social que cria, organiza, expressa e dirige o desejo ${ }^{44}$. A sexualidade, seu exercício e agenciamento estaria na origem da criação dos gêneros feminino e masculino. A teoria marxista é a metodologia de análise da autora, que entende que, assim como a classe dos trabalhadores é definida pela expropriação do trabalho de alguns em benefício de outros, a "expropriação organizada da sexualidade de algumas para o uso de outros define o sexo mulher" ${ }^{45}$. À vista disso, a sexualidade, definida pela autora como aquilo que é erotizado por uma sociedade ${ }^{46}$, é a chave mestra para se entender as dinâmicas de força e as relações de poder na sociedade.

A autora aduz sobre a imposição epistemológica do ponto de vista masculino sobre a realidade. De que forma se conhece o mundo? Ou, melhor, o que faz alguém acreditar conhecer o mundo? Atributos como a neutralidade, a racionalidade e a objetividade geram a sensação de correta, imparcial apreensão da realidade no pensamento político ocidental ${ }^{47}$. A postura científica, não situada, distanciada e neutra é a "postura do conhecedor", daquele que apresenta uma visão verdadeira dos fatos. E por que seria esta uma visão especificamente masculina?

O olhar objetivo sobre a realidade só é passível de ser assumido por aquele que é sujeito. Somente figurando nesta posição pode-se assumir uma postura de transparência diante do objeto sobre o qual se fala; uma posição de imparcialidade e neutralidade. O sujeito é quem olha, observa, analisa; aquele produz entendimento e significado sobre o que está a sua frente, que

\footnotetext{
${ }^{44}$ MACKINNON, Catharine. Desejo e Poder. In: BIROLI, Flavia; MIGUEL, Luis Felipe (Org). Teoria política feminista: textos centrais. São Paulo: Editora Horizonte, 2013. p. 234.

45“"Esse processo cria os seres sociais que conhecemos como homens e mulheres, assim como suas relações criam a sociedade. A sexualidade é para o feminismo- assim como o trabalho para o marxismo- socialmente construída e ao mesmo tempo, construidora. Embora seja historicamente específica, é universal como atividade e composta conjuntamente de matéria e mente.” Ibid., p. 234.

${ }^{46}$ Ibid, p. 239

${ }^{47}$ Ibid, p. 235.
} 
se indaga respeito do que há lá fora. Em outras palavras, o sujeito, diz MacKinnon, é o self, e o objeto é o outro em relação aquele self. Segundo a autora, as conformações dessa postura na linguagem são capazes de explicitar com muita nitidez a perspectiva de sujeito que assume o masculino.

O masculino é tomado como o todo, o genérico, o neutro; a mulher, por sua vez, ocupa posição particular e demarcada pelo gênero, diferenciada, eternamente feminina ${ }^{48}$. A autora também se vale de outros paradigmas para exemplificar as medidas em que o homem é apresentado como sujeito, como na caracterização da mulher como misteriosa no imaginário masculino, aquela a ser desvendada ${ }^{49}$. "Para eles, nós somos o mundo em relação ao conhecimento de mundo" $" 50$. Trata-se de uma forma de situar a mulher como o objeto a ser conhecido- e, consequentemente, sobre o qual se deve agir e por onde se deve explorar. A exploração sexual será uma faceta a nível de práxis dessa lógica.

Se e a objetividade é o ponto neutro e universal pelo qual se apreende a realidade, e se este ponto representa o olhar masculino, é também perante este olhar, formulador de um significado dominante, que será definido o que é homem e o que é mulher. Novamente, o sujeito dessa produção é o homem,

\footnotetext{
${ }^{48}$ MacKinnon escreve em inglês, mas cabe também suscitar as mesmas reflexões quanto a língua portuguesa. A título meramente ilustrativo, é sabido que um grupo que envolve, por exemplo, cinco mulheres e dois homens deverá ser referido como "eles", "aqueles", "esses". A maioria de mulheres no grupo será relevada na designação do todo, que será retratado através de pronomes masculinos. Nesse caso, os homens representam o todo, e as mulheres, o específico. Em outro exemplo, uma mensagem formal endereçada à um coletivo de pessoas cujo número de homens e mulheres é indeterminado também deverá ser iniciada com "prezados", "caros", ou qualquer outro termo com a demarcação masculina. A utilização do masculino como marca da neutralidade é presente.

${ }^{49}$ A autora se vale de um trabalhado por Gayatri Spivak com relação a fingir orgasmos. "Os homens têm ansiedade em relação ao fato de que as mulheres fingem orgasmos. Orgasmos falsos de mulheres como exemplo de algo sobre o qual se pode ter dúvida cartesiana. 'Como eu sei' que ela está satisfeita, certo? Agora considere por que as mulheres fingem orgasmos, em vez de como é ruim que os homens não possam fazê-lo, e, portanto, eles são desiguais a nós. Eu aposto que, se tivéssemos o poder que os homens têm, eles aprenderiam. O que eu estou dizendo é que o poder dos homens para fazer o mundo aqui é o seu poder de nos fazer tornar o mundo de sua interação sexual conosco do jeito que eles querem. Eles querem que nós tenhamos orgasmos; isso prova que eles são viris, potentes, eficazes. Nós lhe damos aparência, seja ela real para nós ou não. Nós até entramos nela. Nossa realidade é: fazer isso, aceitar uma vida inteira de satisfação simulada é muito menos prejudicial para nós do que exigir a coisa de verdade deles" MACKINNON, Catharine. Op. Cit., p. 244.

${ }^{50}$ Ibid., p. 244.
} 
e seu objeto, a mulher ${ }^{51}$; afinal, em termos simples, apreender a realidade através de um enfoque objetivo é objetificá-la. Assim, "a objetividade é a postura epistemológica, da qual a objetificação é o processo social, da qual a dominação masculina é a política ${ }^{52}$, a prática social concretizada em ações"53. Desta forma, a supremacia masculina, observável a nível epistemológico, é também erotizada enquanto ato. A objetificação sexualizada da mulher é o que define o gênero feminino perante o olhar dominante masculino. Nesse mesmo sentido, a pornografia torna o mundo pornográfico através de sua produção e consumo, estabelecendo do que as mulheres são feitas para existir enquanto são reproduzidas e tratadas pela pornografia como objetos ${ }^{54}$. A realidade social do que é a mulher é feita se constrói nos termos do que pode ser feito com ela, e o que é um homem nos termos do que ele pode fazer com ela.

No que denomina de teoria feminista do poder, MacKinnon informa que o sentido social para o qual aponta a sexualidade em um cenário de desigualdades é a erotização da dominação do homem sobre a mulher, processo que caracterizaria a distinção entre gêneros ${ }^{55}$. Para a autora,

\footnotetext{
51 "Assim, quem define o que é objeto "mulher" é o sujeito "homem", e essa perspectiva epistemológica masculina se estende por todas as áreas, tomando o ponto de vista masculino como o ponto de vista objetivo. Se todo o conhecimento foi produzido em um contexto de supremacia masculina, então foi o olhar masculino que orientou a produção do conhecimento humano" TAVARES, Ligia Maria; LOIS, Cecília Caballero. Anotações sobre a teoria feminista do direito de Catharine MacKinnon. Revista de Gênero, Sexualidade e Direito. Curitiba, n. 2, jul/dez. 2016, p. 160.

${ }^{52}$ Vale aduzir que o vocábulo "política", na obra da MacKinnon, é entendido como "relações estruturadas pelo poder, de arranjos pelos quais um grupo de indivíduos é controlado por outro". Ibid., p. 161.

${ }^{53}$ MACKINNON, Catharine. Desejo e Poder. In: BIROLI, Flavia; MIGUEL, Luis Felipe (Org). Teoria política feminista: textos centrais. São Paulo: Editora Horizonte, 2013, p 236.

54 "If objectivity is the epistemological stance of which objectification is the social process, the way a perpetual posture is embodied as a social form of power, the most sexually potent depictions and descriptions would be the most objective blow-by-blow re-presentations. Pornography participantes in its audience's erotism because it creates accessible sexual object, the possession and consumption of which is male sexuality, to be consumed and possessed as which is female sexuality. In this sense, sex in life is no less mediated than it is in art Men have sex with their image of a woman. Escalating explicitness, 'exceeding the bounds of candor', is the aesthetic of pornography not because the materials depict objectified sex but because they create the experience of sexuality that is itself objectified. It is not that life and art imitate each other; in sexuality they are each other". MACKINNON, Catharine. Not a moral Issue. In: CORNELL, Drucilla. Feminism and Pornography. Oxford: Oxford University Press. 2000.

${ }^{55}$ MACKINNON, Catharine. Op. cit., p. 235.
} 
Gênero, neste caso, é uma questão de dominação, e não de diferença. As feministas observaram que mulheres e homens são igualmente diferentes, mas não igualmente poderosos. Explicar a subordinação das mulheres aos homens, uma condição política, nada tem a ver com diferença em sentido fundamental. Consequentemente, tem muito a ver com diferença, já que a ideologia da diferença tem sido tão central na sua aplicação. Outra forma de dizer isso é: não haveria o que conhecemos como diferença de sexo- muito menos isso seria a questão social que é, nem teria o significado social que tem- se não fosse pela dominação masculina. ${ }^{56}$

"O erótico é o que define o sexo como desigualdade" $"$, e o que se erotiza socialmente é a subordinação da mulher enquanto objeto ao homem. Não é a diferença, então, que funda o gênero, mas a dominação. A disparidade entre homens e mulheres como a conhecemos reside na detenção de poder de um em detrimento ao outro ${ }^{58}$. As relações de gênero são por esta via necessariamente assimétricas, e a separação hierárquica entre homens e mulheres atende a propósitos políticos. A comprovação pragmática deste "monte de retórica", nas palavras de MacKinnon, estaria manifestada nos fatos em que se baseia para afirmar a existência de uma dominação masculina conformadora da realidade. Neste momento da Conferência são enunciadas as espantosas taxas de estupro, abuso, assédio, tráfico sexual e comercialização do corpo da mulher nos Estados Unidos ${ }^{59}$. Para MacKinnon, naturalização de tais práticas de violência e subjugação do feminino só poderiam advir de uma dominância deste ponto de vista objetificante da

\footnotetext{
${ }^{56}$ Ibid, p. 236.

${ }^{57}$ Ibid, p. 235.

58 “Às vezes as pessoas me perguntam 'quer dizer que você acha que não há diferença entre homens e mulheres?'. Só conheço uma resposta a isso: é claro que há; a diferença é que os homens têm poder e as mulheres, não. Quero dizer simplesmente que os homens não são socialmente supremos e as mulheres subordinadas por natureza; o fato de eles o serem socialmente construía a diferença de sexo como a conhecemos. O que eu quero é sugerir que o sentido social da diferença- nisso eu incluo différance- é baseado em gênero". Ibid, p. 236.

59 Após o oferecimento das estatísticas pela autora, ainda no mesmo sentido, a mesma elucida novamente a ideia exposta. Vale destacar: 'Uso a palavra 'masculino' como adjetivo. A análise do sexo é social e não biológica. Isso não significa isentar alguns homens nem valorizar todas as mulheres, e sim se referir ao ponto de vista a partir do qual esses atos que documentei são praticados, o que os torna invisíveis, gloriosos, glamourosos e normais. Sendo assim, ao dizer masculino, refirome a apologistas desses dados, à abordagem que faz parte desses dados, ao padrão que normalizou esses eventos de modo que eles definem a masculinidade, ao papel sexual masculino e ao modo como esta abordaem encobriu seu gênero para se tornar o padrão". Ibid., p. 238.
} 
mulher a que se refere a autora. Tal avaliação será transportada para os quadros brasileiros de violência contra a mulher no próximo capítulo.

Posto isso, o desejo não pode se tratar de um ímpeto primitivo, présocial ou instintivo, como por muitas vezes é tomado; do contrário, o desejo é criado no bojo das relações sociais, constituído entre interações que refletem estruturas de hierarquia. A análise do sexo é social, e não biológica ou instintiva. Reitera-se que, para MacKinnon, a sexualidade não é transcultural, historicamente imutável ou essencial, mas o que se erotiza em dada conjuntura; em um cenário de relações de poderio masculino sobre a mulher, o desejo será a sua dinâmica interna em manutenção.

Se a sexualidade emana de um contexto em que o homem é predominantemente sujeito e mulher objeto, não serão as mulheres as principais autoras dos sentidos dessa sexualidade: há um “olhar que constrói as mulheres como objetos para o prazer masculino" 60 . Aqui entra a problemática envolvendo a pornografia. A autora critica a pornografia em sua forma e substância; nela, reproduz-se conteúdo que erotiza o menosprezado, o humilhado, o acessível, o que é feito para ser utilizado. Mackinnon pergunta:

Como é que nós, mulheres, passamos a querer o que não é do nosso interesse? Eu acho que o desejo sexual nas mulheres, pelo menos em nossa cultura, é socialmente construído como aquele pelo qual passamos a querer nossa própria aniquilação. Ou seja, nossa subordinação é erotizada como feminina; na verdade, até gozamos com isso de certa forma, embora bem menos do que homens. Essa é a nossa parte nesse sistema que não é do nosso interesse, nossa parte nesse sistema que está nos matando. Estou dizendo que a feminilidade, como a conhecemos, é como passamos a querer a dominação masculina, que, insisto, não é do nosso interesse.

Busca-se explicar do que é feito o consentimento da mulher que se propõe a performar atividade sexual que erotiza sua coisificação e degradação, como na pornografia. Melhor colocando, MacKinnon pontua que a questão não se trata de analisar a qualidade do consentimento da mulher

\footnotetext{
${ }^{60}$ Ibid., p. 239.

${ }^{61}$ Ibid. p. 239.
} 
em si, mas a condição anterior a ele, de sequer ingressar em uma relação na qual o corpo subjugado e comercializado. A análise de MacKinnon sobre a configuração das preferências subjetivas da mulher em contextos de opressão é filiada a uma abordagem substantiva da autonomia. Segundo Flavia Biroli, a análise substantiva ${ }^{62}$ da produção autônoma da mulher concentra-se no conteúdo das escolhas realizadas por ela, o que permite a deflagração de problemas como o da internalização de normas e valores de caráter opressivo que acabam por solidificar premissas falsas na base íntima de valores de uma mulher ${ }^{63}$.

Nesse quadro, a decisão de uma mulher pode ser formalmente livre, no sentido de formular-se na ausência de constrangimentos e pressões e, assim, ingressar no conceito de Ronald Dworkin de liberdade como vimos no capítulo anterior. Mas a relação entre autonomia e falta de pressões na definição de suas preferências demanda que sejam levadas em conta as relações assimétricas que permeiam este processo. Em outras palavras, entre a livre tomada de decisão e a ausência de constrangimento há os mecanismos de opressão que atravessam a vida de uma mulher. Segundo este entendimento, o consentimento não pode reduzido a uma mera anuência sem

\footnotetext{
${ }^{62}$ Oposta a abordagem substancial da autonomia encontra-se a abordagem procedimental da mesma, realizada por algumas correntes feministas. Flavia Biroli aponta que "as abordagens procedimentais se definiram pela neutralidade em relação ao conteúdo das preferências assumidas pelos indivíduos. São procedimentos na definição das preferências e condutas que permitem observar em que medida há de fato autonomia". (BIROLI, Flavia. Agentes imperfeitas: contribuições do feminismo para a análise da relação entre autonomia, preferências e democracia. Revista Brasileira de Ciência Política. Brasília, n. 9, p. 7-38, set./dez. 2012). Assim, a presença de autoentendimento refletido ou coerência interna com a escolha, associada ausência de coerção a manipulação alheia pode levar a uma livre escolha em um cenário social de igualdade.

${ }^{63} \mathrm{~A}$ esse respeito, MacKinnon e Dworkin fazem referência a estudos datados do final dos anos oitenta que indicam ser a maior parte das mulheres em atuação na indústria pornográfica vítimas de abuso sexual na infância. "The women in pornography are most often victims of child sexual abuse. Some studies show that 65 to $75 \%$ of the current population of women in prostitution and pornography (overlapping experiences for the same pool of women) have been abused as children, usually in the home. People who work with women who are in pornography and prostitution to provice social services or counselling, some of whom have been in pornography and prostitution themselves, believe the percentage is much, much higher.Women in pornography are poor women, usually uneducated. Pornography existis in a society in which women make more money than men and are modeling and prostitution- and in prostitution, the pimps keep most if not all of it. Women's economic value is determined largely by sexual value: how much the woman's body is with in the marketplace as a commodity." DWORKIN, Andrea; MACKINNON, Catharine. Pornography and Civil Rights: A new day for women's equality. Nova Iorque: Organizing Against Pornography: A Resouce Center for Education and Action. 1988, p. 70.
} 
coerção: a substância da autonomia é afetada no caminho da escolha. A análise crítica das preferências subjetivas e do consentimento conecta-se, assim, a crítica ao voluntarismo predominante nas teorias liberais clássicas e contemporâneas.

O foco nas relações desiguais de poder entre homens e mulheres faz com que as escolhas destas sejam vistas não apenas como um resultado da interação entre o indivíduo e as alternativas disponíveis, mas também como um desdobramento complexo dos padrões de socialização ${ }^{64}$. De acordo com a abordagem substantiva da autonomia, as próprias alternativas disponíveis a mulher se revelam limitadas; o horizonte de possibilidades, o que é percebido como possível já se encontra adstrito a um recorte restrito de opções. Com efeito, vale tomar como exemplo o caso de uma mulher que ingressa no mercado da pornografia através da anuência da divulgação de seu vídeo realizando sexo oral em determinado homem. A veiculação deste material em plataformas de ampla circulação na internet e nas redes sociais levam-na a quase inevitável degradação de sua imagem em uma sociedade machista. O reingresso no mercado de trabalho formal- que, por sua vez, já apresenta por si só condições desiguais de desenvolvimento profissional da mulher ${ }^{65}$ é, no mínimo, temporariamente impossibilitado, se não permanentemente obstruído em seus potenciais originais ${ }^{66}$. Por outro lado, utilizando-se da sugestão de MacKinnon, a mera possibilidade de se lucrar com a exploração do próprio corpo, a própria existência de um mercado que comercializa não

\footnotetext{
${ }^{64}$ BIROLI, Flavia. Agentes imperfeitas: contribuições do feminismo para a análise da relação entre autonomia, preferências e democracia. Revista Brasileira de Ciência Política. Brasília, n. 9, p. 7-38, set./dez. 2012, p. 16.

${ }^{65}$ Dados sobre a disparidade social na contemporaneidade foram explicitadas no capítulo anterior deste trabalho.

${ }^{66} \mathrm{O}$ caso de Belle Knox, nome artístico da atriz pornô Miriam Weeks, pode ser considerado representativo desta situação. Para arcar com os custos da faculdade de Direito na Universidade de Duke, nos Estados Unidos, que somam 60 mil dólares por ano, a jovem de 18 anos entrou em contato com agências de modelo que clandestinamente recutravam mulheres interessadas em trabalhar na indústria pornográfica e rapidamente começou a produzir filmes. Belle Knox figura hoje na $53^{\mathrm{a}}$ posição no ranking de atrizes pornôs mais buscadas no site pornhub.com. Em documentário recentemente lançado, a atriz afirma saber que, desde que teve sua profissão revelada na universidade por um colega de sala, suas perspectivas profissionais se limitaram drasticamente. Informações disponíveis em: http://www.huffpostbrasil.com/2014/09/16/belle-knox-teradocumentario-sobre-como-uma-garota-de-18-anos-vi_a_21679908/. Acesso em 23/05/2017.
} 
o sexo em si, mas o sexo feminino, já anuncia as configurações distorcidas pelo patriarcado no horizonte de possibilidades de uma mulher.

A correlação pretendida por Catharine MacKinnon entre privacidade, autonomia e dominação perpassa esse raciocínio. Não se pode pensar em sexualidade e desejo sem abordar a normalização do estupro na sociedade, ou falar sobre ciência sem mencionar sobre o caráter masculino de suas premissas. É impossível tratar de uma lógica hegemônica dominante sem citar a dominação masculina como uma de suas formas. A vida cotidiana é atravessada por reproduções sistemáticas da violência de gênero; para mudar a realidade é necessário entender a perversidade da dinâmica, enxergá-la para não reproduzi-la consciente ou inconscientemente. A pornografia traz sua condição de produção para o consumidor: a dominância. O consumidor, por sua vez, assimila como desejável o conteúdo assistido; conteúdo, esse, de subjugação feminina ao masculino. Quanto a mulher, ser subordinada a dominância na pornografia é reproduzir um significado de que não se tem domínio, falar a língua de outrem ${ }^{67}$ ou um idioma que não é seu.

\subsection{O discurso enquanto ação}

“O que se faz na pornografia não é um sexo real no sentido de um ato cuja intimidade é verdadeira e compartilhada. Isto pode fazer desse sexo uma mentira, mas não o fará simulado"68. Essa é uma entre as premissas mais importantes na edificação do argumento de MacKinnon e Dworkin, substrato teórico capaz de conferir formatação jurídica para as pretensas antipornografia das autoras. Na obra "Only Words", de 1993, Catharine MacKinnon caracteriza a pornografia como um discurso que atua a discriminação e não apenas a representa. A autora se contrapõe ao tratamento

\footnotetext{
67 "Subordination is doing someone else's language", FROMAN apud. MACKINNON, Catharine. Only Words. Harvard: Harvard University Press. 1993, p. 25.

68 "No pornography is "real" sex in the sense of shared intimacy; this may make a lie, but it does not make it "simulated". Ibid., p. 27
} 
legal historicamente destinado à pornografia nos Estados Unidos e endossado por decisões dos tribunais superiores.

A pornografia no direito norte-americano é revestida de proteção constitucional. Desde o início do século XX, o Judiciário americano era convocado a se pronunciar a respeito da possibilidade de se censurar material sexualmente explícito ${ }^{69}$. O caso Roth vs. United States, datado de 1957, tratava-se de um exemplo deste tipo e demarcou uma mudança de paradigma no tratamento reservado a questão. No caso, o cidadão Samuel Roth havia sido condenado com base em lei federal por postagem de material obsceno e teve sua sentença mantida pela Suprema Corte. Afirmou-se, naquele momento, o que viria a constituir a base nuclear do entendimento judicial sobre pornografia nos Estados Unidos: somente o material pornográfico compreendido como obsceno não merece o amparo constitucional da Primeira Emenda ${ }^{70}$. A obscenidade é retirada do âmbito de tutela constitucional, e o material sexualmente explícito que não se constitui como obsceno figura como desdobramento legítimo do direito ao livre discurso.

\footnotetext{
${ }^{69}$ Sobre o tratamento anterior a 1957 destinado à censura, Júlio Cesar Casarin Barroso Silva disserta que "até bem entrado o século XX, era bastante comum que tribunais estadunidenses apoiassem a censura a obras literárias de mérito insuspeitável, como O amante de Lady Chatterly, Ulisses e obras de Balzac. Ulisses foi proibido em 1920 a pedido da "Sociedade de Nova Iorque pela Supressão do Vício" pelo fato de que o personagem principal do romance se masturba em determinado ponto da narrativa. O critério judicial que ensejou esta censura (e que ensejava censura por obscenidade então), chamado teste Hicklin e forjado no âmbito do direito comum britânico, determinava a censura "se a tendência do material acusado de obscenidade é corromper aqueles cujas mentes estão abertas a tais influências imorais e em cujas mãos uma publicação deste tipo pode cair", referindose com isso a crianças e a pessoas com deficiências mentais graves. (...) A retenção da versão francesa de Ulisses na alfândega acabou por desencadear um processo judicial, decidido por um juiz federal cujo resultado foi a ampliação do critério, pois o julgamento passou a ser feito com base no efeito de seu "tema dominante" (e não mais pela existência de um trecho qualquer) sobre o "leitor médio" (e não mais sobre os mais vulneráveis). Apesar de não ter sido decidido pela Suprema Corte, este caso tornou-se amplamente adotado como critério, ou foi tão amplamente adotado como pode sê-lo uma decisão não testada pela Corte Constitucional. Depois de a Corte Suprema ter permitido nos anos de 1940 a censura de um romance de um dos maiores críticos literários dos Estados Unidos, Edmund Wilson, deu-se continuidade ao abrandamento dos termos de moralidade sexual como causa de censura. Mas a derrogação explícita do critério Hicklin só viria com a decisão de Roth v. United States." SILVA, Julio César Casarin Barroso Silva. Liberdade de expressão, pornografia e igualdade de gênero. Revista Estudos Feministas. Florianópolis, n. 1, p. 143-165, jan./abr. 2013.

${ }^{70}$ A Primeira Emenda à Constituição norte-americana possui a seguinte redação: "O Congresso não legislará no sentido de estabelecer uma religião, ou proibindo o livre exercício dos cultos; ou cerceando a liberdade de palavra, ou de imprensa, ou o direito ao povo de se reunir pacificamente e de dirigir ao Governo petições para a reparação de seus agravos".
} 
Apesar da manutenção da condenação de Roth, observou-se na decisão do tribunal superior a tentativa de restringir o conceito de obscenidade. Segundo o entendimento do juiz William Brennan, em voto monocrático, para ser considerado obsceno "o tema dominante do material tomado em seu conjunto" deveria "apelar para interesses lascivos" perceptível pelo critério do "homem médio", o qual, por sua vez, deveria julgar de acordo com os "padrões comunitários contemporâneos". Brennan ainda estabelecia uma ressalva: a de que a censura só poderia ser estendida aos casos desprovidos de "mínima relevância social" que fosse capaz de o "redimir". Desta forma, ainda as ideias que parecessem "odiosas ao clima predominante de opinião" não poderiam ser qualificadas como obscenas ${ }^{71}$.

Em 1964, no emblemático caso Jacobellis vs. Ohio, a caracterização definida na decisão anterior foi posta a prova, levando o juiz Justice Stewart a entoar a famosa frase "eu não sei definir pornografia, mas reconheço-a quando a vejo". Estatuiu-se que as leis anti-obscenidade só poderiam ser aplicadas a pornografia hardcore, muito embora não parecesse ser possível conceituá-la. Ao longo desta década, a Suprema Corte buscou reelaborar o critério Roth sem alterá-lo em profundidade. Estabeleceu-se, a partir de casos concretos, que para não gozar da tutela constitucional o material em questão deveria ter a função de satisfazer a "interesses lascivos" de "modo patentemente ofensivo" e carecer de qualquer "valor social" capaz de o redimir, devendo esses três requisitos estarem presentes simultaneamente. No caso Miller vs. California, de 1973, interesse lascivo foi qualificado como "material que mostra ou descreve de um modo patentemente ofensivo conduta sexual tal como definida em lei estadual", delegando o padrão comunitário em que deveria ser pautada essa noção a esfera local, e não nacional. Novamente, entendeu-se que só poderia ser considerado obsceno o

\footnotetext{
${ }^{71}$ SILVA, Julio César Casarin Barroso Silva. Liberdade de expressão, pornografia e igualdade de gênero. Revista Estudos Feministas. Florianópolis, n. 1, p. 143-165, jan./abr. 2013. Disponível em: http://www.scielo.br/scielo.php?script=sci_arttext\&pid=S0104-026X2013000100008\#back22. Acesso em 07 jun. 2017.
} 
material que não provesse de qualquer valor literário, político, artístico ou científico.

É de suma importância para a cultura jurídica norte-americana manter a promoção de uma leitura aberta e quase irrestrita da Primeira Emenda. Nesse contexto, a constrição da liberdade de expressão é entendida como medida a ser tomada mais que excepcionalmente. Na conceituação do obsceno como aquilo que não deverá ser contemplado pelo alcance constitucional percebe-se o reflexo desta lógica. Julio Cesar Barroso da Silva, na revista Estudos Feministas, apontou que:

Na prática, e provavelmente contra a vontade daqueles que o elaboraram, o critério Miller é altamente protetivo de expressão com caráter sexual. O que lhe dá esse caráter protetivo é a exigência de que manifeste um "interesse lascivo" de forma "patentemente ofensiva". Como remete a estados psicológicos raramente confessados, é incomum que júris e juízes consigam prová-lo. Cass Sunstein afirma que é muito difícil vencer um processo por obscenidade a menos que o material em questão seja apenas uma incitação à masturbação, e acrescenta: 'apesar de alguns processos frívolos e de grande publicidade [...], falando de modo realista, pessoas envolvidas na produção de trabalhos sexualmente explícitos têm pouco a temer do critério Miller'.

Desta forma, sob a égide da Primeira Emenda, instituidora da liberdade de expressão e do livre discurso nos Estados Unidos, a pornografia foi definitivamente permitida por entendimento consagrado pela Suprema Corte. A esse respeito, Catharine MacKinnon nota que a análise judicial sobre pornografia permaneceu a todo tempo congelada nos moldes do clássico debate livre expressão versus censura estatal. Debater pornografia tornou-se discutir o avanço tirânico da autoridade governamental sobre a criação artística e o direito ao dissenso, muito embora a complexidade e singularidade do tema lançasse o debate para muito além desta tradicional estrutura de controvérsia liberal que opõe indivíduo e Estado ${ }^{72}$.

Formalmente categorizada como discurso, os elementos vinculados a pornografia passaram a ser vistos como "mensagens", "emoções” ou "pontos

\footnotetext{
72 "Frozen in the classic form of prior debates over censorship of political and artistic speech, the pornography debate thus became one of governmental authority threatening to suppress genius and dissent." MACKINNON, Catharine. Only Words. Harvard: Harvard University Press. 1993 , p. 8.
} 


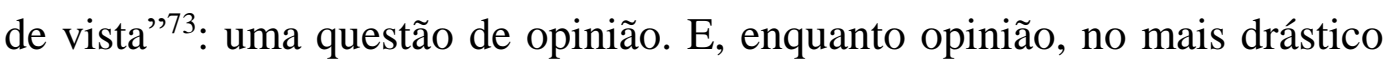
cenário sua exibição pode vir a difamar mulheres. Sendo a difamação o risco majoritário da pornografia, convenciona-se rapidamente que seu material, conteúdo potencialmente desagradável a determinado grupo de pessoas, merece o resguardo da Primeira Emenda. Afinal, a liberdade de expressão abarca também, e talvez principalmente, a liberdade de criticar, discordar e, consequentemente, ofender.

MacKinnon disserta que por trás deste raciocínio há uma espécie de radicalismo ideológico que visa proteger quase automaticamente qualquer prática cuja aparência é de discurso, antes mesmo de se refletir a respeito de seu conteúdo ou sobre o perigo de seus efeito. Segundo a autora, trata-se de uma tendência sociocultural norte-americana a de resistir veementemente a qualquer vislumbre de restrição discursiva por parte do Estado. Um assombro ronda a possibilidade de se conter a veiculação de ideias. Por um lado, há uma noção amplamente disseminada de que jamais caberá ao governo avaliar a qualidade de um discurso ou sua legitimidade democrática. Perante os olhos do Estado, qualquer ideia é neutra, havendo apenas graduações no seu potencial ofensivo. Por outro, são temidos os efeitos da limitação de discurso, facilmente escapáveis ao controle; acredita-se que a censura nunca é satisfatoriamente criteriosa e que suas pretensões podem eventualmente tomar proporções tirânicas, atingindo a qualquer um. Tal postura, contudo, por vezes extrapola qualquer razoabilidade ao promover uma verdadeira cegueira estatal a graves práticas de discriminação revestidas de livre discurso. Indiscriminadamente, opera-se um "zelo fundamentalista" a qualquer discurso, inclusive aquele que serve ao encobrir mentiras, silenciar seres humanos, destruir carreiras e retardar mudanças. ${ }^{74}$

\footnotetext{
${ }^{73}$ Ibid., p. 10

74 "In this faith, restricting some speech can only eventuate in restricting more or all speech: the "slippery slope" hazard. Restricting speech is seen to be tempting, to have seductive power that draws governments to its totalitarian- also regarded as principled- logic: if we restrict this bad thing now, we will not be able to stop ourselves from restricting this good thing later. One corollary is that everyone has an interest in everyone else's speech being free, because restriction will get around to you eventually; the less power you have, the sooner it will get around you. Crucial is that speech
} 
Segundo com o ideário que entende a pornografia como passível de proteção pela Primeira Emenda, suas palavras e imagens teriam uma relação meramente referencial com a realidade, não sendo elas mesmas capazes de transformar qualquer cenário fático. A estratégia teórica de MacKinnon consiste em refutar enfaticamente esse postulado. A pornografia, sim, trata de um discurso, mas não só disso. A pornografia $f a z$, não apenas diz. Como qualquer outra prática social, a pornografia contém ideias; ainda assim, a forma com que opera não é somente através da veiculação delas, pela transmissão de pensamentos- ao menos não como outras ideias e práticas protegidas pelo livre discurso o são. Seu papel no abuso de mulheres é ativo, não passivo; constrói e endossa a violência de gênero muito mais do que simplesmente se refere a ela ${ }^{75}$.

Isto porque a linguagem imbuída no discurso pornográfico sugestiona um complexo padrão de comportamento, ao mesmo tempo instaurando uma expectativa entorno dos papeis desempenhados no ato sexual e promovendo associações imediatas entre violência, dominação e prazer. Nas imagens, a mulher se volta inteiramente ao desejo masculino. Seu prazer é acionado a partir e na medida de seus comandos. Desta forma, ainda que tenha seu corpo dilacerado, seus órgãos genitais torturados, todos os seus orifícios penetráveis simultaneamente preenchidos por diversos homens, sua imagem denegrida por humilhações verbais, sua garganta forçada contra um pênis até

\footnotetext{
cannot be restricted because you fear its consequences: the "bad tendency" of "witch-hunt" doctrine. If some speech is conceded to be risky, more speech to the contrary will eliminate that risk. Most of all, government can make no judgment to a content. For constitutional purposes, there is no such thing as a false idea, there are only more or less "offensive" ones, to remedy which, love of liberty recommends averting the eyes or growing a thicker skin. Americans are taught this view by about the fourth grade and continue to absorb it through osmosis from everything around them for the rest of their lives, including law school, to the point that those who embrace it think it is their own personal faith, their own original view, and trot it out like something learned from their own personal lives every time a problem is denominated of "speech", whether it early fits or not. Any issue that strikes this chord, however faintly, gets played this tune, even if the consequences are more like a replay of McCarthyism than resistance to it. This approach is adhered to with a fundamentalist zeal even when it serves to protect lies, silence dissent, destroy carreers, intrude on associations, and retard change." Ibid., p. 76-77.

75 "Pornography contain ideas, like any other social practice. But the way it works is not as a thought or through its ideais as such, at least not in the way thoughts and ideas are protected as speech. Its place in abuse requires understanding it more in active than in passive terms, as constructing and performative rather than as merely referential or connotative" Ibid., p. 21.
} 
que a sufocação a faça vomitar, no rosto da mulher persiste o sorriso. Equaciona-se prazer feminino a ordem masculina, de maneira que, enquanto o desejo masculino for cumprido, a resposta feminina será sempre positiva: seu sorriso é a comprovação documentada desta regra ${ }^{76}$, contra a qual não há argumentos. Na pornografia, as imagens registradas pela câmera detém uma credibilidade especial, uma verossimilhança inerente, um apelo mais forte a verdade dos fatos ${ }^{77}$. Como poderia uma atriz, que em cena geme e sorri durante o sexo, alegar ter sido estuprada? Mas, se não ela, quem então passa a ter autoridade narrativa para contar o que lhe aconteceu?

MacKinnon e Dworkin argumentam que, especialmente nesse ponto, a pornografia opera um de seus mais perversos efeitos: o silenciamento da mulher, desde a diminuição até o aniquilamento do poder de suas palavras. O discurso sobre sua própria experiência é invalidado; não parece caber a mulher saber a verdade do que lhe ocorreu. O poder de falar sobre si é retirado de sua ordem de domínio. Nesse sentido, entende MacKinnon:

Proteger a pornografia significa proteger o abuso sexual enquanto discurso, ao mesmo tempo em que tanto a pornografia quanto a sua proteção privaram a mulher do discurso, especialmente contra o abuso sexual. Há uma conexão entre o silêncio forçado as mulheres, no qual somos vistas para amar e escolher nossas correntes porque elas foram sexualizadas, e o ruído da pornografia que nos rodeia, passando pelo discurso (o nosso, inclusive) e desfilando sob a tutela constitucional ${ }^{78}$.

A dolorosa narrativa de Linda Lovelace sobre os abusos e coerções sofridas durante a produção do filme Garganta Profunda pareceu representar este movimento. Defendida por MacKinnon em juízo, Linda buscou

\footnotetext{
76 "There is, you find, a whole industry selling cative smilling women to make such pictures, acting as if they like it. When any one of them tries to tell what happened, she is told it did not happen, she imagines it, she wanted it. Her no meant yes. The pictures prove it. See, she smiles." p. 5 only words 77 "In this, the pictures are not so different from the words and drawings that came before, but you use for the camera gives the pictures a special credibility, a deep verisimilitude, an even stronger claim to truth, to being incontrovertibly about you, because they happened and there you are" Ibid., p. 4

78 "Protecting pornography means protecting sexual abuse as a speech, at the same time that both pornography and its protection have deprived woman of speech, specially against sexual abuse. There is a connection between the silence enforced on women, in which we are seen to love and choose our chains because they have been sexualized, and the noise of pornography that surrounds us, passing for discourse (ours, even) and parading under constitutional protection." Ibid, p. 9.
} 
processar os produtores do filme, entre eles seu ex-marido. Tanto a resposta judicial quanto a repercussão pública de seu testemunho apontaram no mesmo sentido: o discurso de Linda parece inaudível, sua palavra é desacreditada, sua história, falaciosa. "Você aprende que sua linguagem não pertence a você, que você não pode usá-la para dizer o que sabe, que a informação não é feita da sua experiência" ${ }^{\text {"79. }}$.

Desta forma, argui-se a existência de um estreito vínculo que parece conectar o que é apresentado na pornografia e a tática sistemática de esvaziamento do discurso da mulher em casos de abuso e violência sexual. As palavras e imagens veiculadas na pornografia não são simplesmente reproduzidas; nas palavras da autora, seu conteúdo gera intrusão mental inconsciente $^{80}$. Os consumidores do material que exibe a exploração e subordinação sexual da mulher passam a naturalizar aquelas formas de violência. Parece lógico que, se o acesso a pornografia é motivado pela busca de excitação, e se o consumidor se masturba e tem prazer com aquele material, é provável que ele vá querer reproduzi-lo em sua realidade ${ }^{81}$. Assim cria-se um circuito de reprodução da violência de gênero durante a produção e em razão do consumo de pornografia, em constante retroalimentação.

\footnotetext{
79 "You learn that language does not belong to you, that you cannot use it to say what you know, that knowledge is not what you learn from your life, that information is not made out of your experience. (...) You learn that your reality subsists somewhere beneath the socially realm- totally exposed but invisible, screaming yet inaudible, thought about incessantly yet unthinkable, 'expression' yet inexpressible, beyond words. You learn that speech is not what you say but what your abusers do to you" Ibid., p. 6.

80 "It is to question the extent to which the First Amendment protects unconscious mental intrusion and physical manipulation, even by pictures and words, particularly when the results are further acted out through aggression and other discrimination. It is also to observe that pornography does not engane the conscious mind in the chosen way the model of 'content', in termos of which it is largely defended, envisions and requires" Ibid, p. 16.

81 "A great many people know a great deal about pornography from rather intimate acquaintance. They use it. They enjoy it. In particular, they masturbate with it. Once- and studies have shown this and is something women know from their own experience- once one has had an orgasm with pornography, particularly if one has done it from being very young and over time, that then becomes what sexuality is. So that, when you enjoy it in that way, you are very less likely to see that the person who was used in that way was hurt or was simply used so that you could use her. And you are also less likely to see that, for instance, someone who has been victim of a rape, when they are telling you what the rape was, one is less likely to see that that was rape. Pornography desensitizes men, the consumer, to women's pain, particularly when it is done through sex. It desensitizes the viewer to violence against women, and makes one think that that's what women want, that's what women really are like, that's what women enjoy, that's what a woman's sexuality really is, that's how women are fulfilled." Trecho da entrevista de Catharine MacKinnon no programa televisivo The Open Mind. Disponível em: https://www.youtube.com/watch?v=Z9J-oYbxP4Q.
} 
Esta é a premissa central de seu tese; a pornografia é caracterizada como um discurso que produz efeitos e endossa práticas. A autora estabelece um paralelo entre a dimensão atuante da pornografia e certas injúrias raciais. As enunciações "Apenas brancos", ou "Judeus não são bem-vindos", se inseridas por escrito em uma placa em frente a determinado estabelecimento, não apenas comunicam uma ideia. Tais dizeres são discriminações em si mesmo, inteiramente responsáveis por gerar a violação de direitos civis garantidos pelo entendimento constitucional norte-americano. A intenção por trás desses dizeres é a segregação, assim como o que se produz com esses dizeres é a segregação. Tais palavras são e geram, ao mesmo tempo, atos. O discurso pornográfico age de forma similar. A pornografia é uma prática discursiva constitutiva; ela atua a discriminação sexual da mulher e produz como efeitos seu silenciamento e objetificação.

O que MacKinnon pretende questionar é até onde deve se estender a proteção da Primeira Emenda. Afirma que, se a pornografia é ao mesmo tempo prática discriminativa e núcleo de proteção constitucional, então igualdade e liberdade entram em colisão no debate a seu respeito. Para a autora, doutrina constitucional da liberdade de expressão nos Estados Unidos foi desenvolvida sem que fosse levada a conta a importância da igualdade, tutelada pela Décima Quarta Emenda à Constituição. Em suas palavras, “a Primeira Emenda evoluiu como se o comprometimento com a igualdade não tivesse qualquer implicação na liberdade de expressão" 82 . Se o resguardo constitucional da pornografia garante o discurso de uns e promove o silenciamento de outros, então a promoção da igualdade está em cheque.

\subsection{Uma roupagem legal à pornografia: a proposta do combate}

Em 1983, Catharine MacKinnon e Andrea Dworkin tentaram fazer promulgar as ordenações de Mineápolis e Indianápolis, leis civis contra a pornografia. O projeto elaborado pelas autoras tratava de uma tentativa de

\footnotetext{
${ }^{82}$ Ibid., p. 71
} 
disciplinar a produção, venda, exibição e distribuição de material pornográfico, cujo conceito abarcava, além de um substrato genérico, também um rol contendo diversas formas de exploração e subordinação sexual da mulher que a exibição gráfica poderia tomar, fosse através de imagens ou palavras. Nos termos do próprio artigo:

Pornografia é a subordinação sexual gráfica explícita da mulher através de imagens e/ou palavras, que podem incluir uma ou mais das seguintes características:

(i) mulheres sendo apresentadas como objetos sexuais desumanizados, coisas ou bens de consumo,

(ii) mulheres sendo apresentadas como objetos sexuais que gostam da dor ou da humilhação,

(iii) mulheres sendo apresentadas como objetos sexuais que experimentam prazer sexual enquanto são estupradas,

(iv) mulheres sendo apresentadas como objetos sexuais sendo enforcadas, cortadas, mutiladas, machucadas ou fisicamente cortadas,

(v) mulheres sendo apresentadas em posturas ou posições de submissão sexual, servilidade ou exposição,

(vi) exibição e redução da mulher às partes dos seus corpos, incluindo nào apenas vaginas, seios ou nádegas,

(vii) mulheres apresentadas como prostitutas por natureza,

(viii) mulheres sendo penetradas por objetos ou animais,

(ix) mulheres sendo apresentadas em cenários de degradação, dano, tortura, sendo exibidas como imundas ou inferiores, sangrando, machucadas ou mutiladas em condições sexuais.

O uso de homens, crianças ou transexuais no lugar das mulheres no parágrafo anterior também caracteriza a pornografia. ${ }^{83}$

A perspectiva de restrição contida no texto normativo não pretendia alcançar qualquer material sexualmente explícito. A objeção era destinada, exclusivamente, a pornografia que viesse a apresentar mulheres coagidas, abusadas, dominadas ou degradadas de forma a endossar sua subjugação. Em Pornography and Civil Rights: A New Day For Women's Equality, lançado em 1988, as autoras dissertaram a respeito de cada ponto juridicamente relevante contido nas ordenações. Na seção "Definição", Dworkin e

\footnotetext{
${ }^{83}$ DIAS, Carolina Bouchardet. Impactos da pornografia na saúde dos adolescentes: uma análise a partir dos direitos fundamentais. Disponível em http://www.pucrio.br/pibic/relatorio_resumo2016/relatorios_pdf/ccs/DIR/DIR-Carolina_Dias.pdf. Acesso em 07 jun. 2017.
} 
MacKinnon esclareceram que qualquer um que desejasse se utilizar da lei civil anti-pornografia deveria comprovar, preliminarmente, o cabimento do material atacado no conceito legal de pornografia ${ }^{84}$. Esta seria uma das balizas possíveis ao acolhimento da ação.

Apresentar uma mulher em condição de subordinação, de inferiorização ou menosprezo figuraria como requisito necessário para se considerar o material pornográfico. Sendo assim, a relação entre pornografia e ilegalidade não seria automática. Nunca se pretendeu que fosse. O conceito de pornografia como apresentado nas ordenações era fechado, concreto e descritivo; não ensejava uma leitura aberta ou de ordem moral. Estabelecer um crivo conceitual era, para as autoras, uma forma de impedir que a lei fosse mal utilizada ou tivesse seu propósito deformado ${ }^{85}$. Este, por sua vez, era o de facilitar o acesso da mulher ao Judiciário, conferindo-lhe a chance de comprovar em juízo que determinado material pornográfico é capaz de causar dano.

As autoras aludiram que a lei só incidiria sobre aquele material que efetivamente subordinasse mulheres em seu conteúdo, durante sua produção ou em decorrência de seu consumo. Sabe-se, pelo que foi aduzido nos últimos subcapítulos, que na edificação teórica das autoras a pornografia e a prática de violência e abuso sexual ora representam a mesma coisa, ora possuem intrínseca relação de causalidade. Os argumentos fundadores destas afirmações possuem razoável aceitação ou plausibilidade acadêmica e retórica. Não obstante, para que os projetos de lei fossem aprovados pelas câmaras municipais de Indianápolis e Mineápolis, era necessário que se

\footnotetext{
${ }^{84}$ DWORKIN, Andrea; MACKINNON, Catharine. Pornography and Civil Rights: A new day for women's equality. Nova Iorque: Organizing Against Pornography: A Resouce Center for Education and Action. 1988, p. 35.

85 "Anyone who brought a case under the Ordinance would have to prove that the challenged materials actually subordinated women in their making or use in order to show that the materials were pornography. In other words, the fact that a legislature finds that pornography subordinates women enough to pass a law does not mean that all materials that someone might think are pornography are automatically illegal. It only gives women a chance to try to prove in court that specific materials are pornography because they actively subordinates women (and meet the other requirements), therefore fit the definition. The definition is closed, concrete and descriptive, not open-ended, conceptual or moral. It takes the risk that all damaging materials might not be covered in order to try to avoid misuse of the law as much as possible.” Ibid., p. 39.
} 
demonstrasse de forma mais pragmática as correlações possíveis entre episódios de violência contra mulher e a produção ou consumo de pornografia. Buscava-se uma base factual que pudesse demonstrar a relevância e conveniência da lei. Audiências públicas que visavam inquirir os efeitos potencialmente danosos da pornografia foram realizadas com esta finalidade. $\mathrm{O}$ resultado das audiências foi a reunião de inúmeros relatos de agressão, estupro, abuso e assédio que possuíam relação direta com a pornografia, reportados em Pornography and Civil Rights: A New Day For Women's Equality 86.

Ao contrário do que muito se afirma, a norma intencionada por MacKinnon e Dworkin não criminalizava a venda ou consumo de material pornográfico. As ordenações não buscavam impor proibições ou sanções criminais a pornografia. Sua proposta era a de implementar medidas civis ("civil remedies") que possibilitariam mulheres afetadas pela produção de materiais pornográficos, ou em razão de seu consumo, de processar os responsáveis pela confecção, veiculação ou reprodução forçada de seu conteúdo. O projeto de lei elencava quatro práticas passíveis de ensejar ação civil: coerção na realização de pornografia ("coercion into pornography") ${ }^{87}$,

\footnotetext{
86 "In Minneapolis, where the Ordinance was first introduced in late 1983, the City Council held public hearings to inquire into effects of pornography and to provide the basis for a civil rights law against it. Based on these hearings, and expanded and reconfirmed through the efforts of people in many communities, the Ordinance's findings outline a range of harms from the individual and intimate to the social and anonymous. In the hearings, women and men spoke in public for the first time in the history of the world about the devastating impact pornography has had on their lives. They spoke of being coerced into sex so that pornography could be made of it. They spoke of pornography being forced on them in ways that gave them no choice about seeing the pornography or later performing the sex. They spoke of rapes patterned on specific pornography that was read to them during the rape, repeated like a mantra throughout the rape; they spoke of being tuned over as the pages were turned over. They spoke of the sexual harassment of living or working in neighborhoods or job sites saturated with pornography. A young man spoke of growing up gay, learning from heterossexual pornography that to be loved by a man meant to accept his violence, and as a result accepting the destructive brutally of his first male lover. Another young man spoke of his struggle to reject the thrill of sexual dominance he learned from pornography and to find a way of loving a woman that was not part of it. A young man spoke of her father using pornography on her mother, and using it to keep her quiet about her mother's screams at night, threatening to enact the scenes on the daughter as well if she told anyone.". Mais relatos obtidos nas audiências públicas podem ser obtidos nas páginas 34 e 45 de Pornography and Civil Rights: A New Day for Women's Equality.

${ }^{87}$ A redação expressa da lei versava: "It shall be sex discrimination to coerce, intimidate or fraudulently induce (hereafter, 'coerce') any personon, including transexual, into performing for pornography, which injury may date from any appearance or sale of any product(s) of such
} 
forçar pornografia em alguém ("forcing pornography on a person") ${ }^{88}$, agressão em função de material pornográfico ("assault or physical attack due to pornography") ${ }^{89}$ ou traficar materiais pornográficos ("trafficking in pornography") ${ }^{90}$. Da redação direta do texto legal extrai-se que:

Qualquer pessoa atingida pelas violações previstas nesta lei poderá fazer cumprir suas disposições por meio de ação civil proposta no foro competente. Não deverão ser aplicadas penalidades criminais a qualquer violação desta lei ${ }^{91}$.

$\mathrm{Na}$ verdade, as autoras acreditavam que punir criminalmente a produção, publicação ou consumo de pornografia seria contraproducente, tendo em vista que deslocaria a indústria para o mercado ilícito e obscureceria mais ainda seus malefícios causados as mulheres. Não era almejado um banimento a priori da pornografia. Somente o material pornográfico atingido por essas ações civis cabíveis, com seu dano comprovado, poderia ter sua circulação banida a posteriori e ilegalidade declarada.

Grandes referências do pensamento liberal ocidental apresentaram ferozes críticas as propostas legislativas de Dworkin e MacKinnon. Ronald Dworkin, mencionado no primeiro capítulo deste trabalho como um dos expoentes da teoria liberal contemporânea, relutou contra a proposta de combate a pornografia alegando principalmente a fragilidade na demonstração empírica de seus malefícios ao coletivo. Em carta pública endereçada à MacKinnon, Dworkin firma seu argumento central na ausência

performance(s). The maker(s), seller(s), exhibitor(s), and/or distributor(s) of said pornography may be sued for damages and for an injunction, including to eliminate the product(s) of the performance(s) from the public view". DWORKIN, Andrea; MACKINNON, Catharine. Op. Cit., p. 41.

88 "It shall be sex discrimination to force pornography on a person, including child or transsexual, in any place of employment, education, home or public space. Only the perpetrator of the force or institution responsible for the force may be sued." Ibid., p. 49.

89 "It shall be sex discrimination to assault, physically attack or injure any person, including child of transsexual, in a way that is directly cause by specific pornography. Complaint(s) may be made against the perpetrator of the assault or attack and/or against the maker(s), distributor(s), seller(s), and/or exhibitor(s) of the specific pornography". Ibid., p. 49

90 "It shall be sex discrimination to produce, sell, exhibit, or distribute pornography, including through private clubs.” Ibid, p. 44.

91 "Any person aggrieved by violations of this law may enforce its provisions by means of a civil action filled in a court of competent jurisdiction. No criminal penalties shall attach for any violation of this law”. Ibid., p. 53 
de evidências confiáveis que comprovem a associação entre circulação de material pornográfico e as estatísticas concernentes a violência de gênero. Nesse sentido, o autor aduz que, na contramão do que afirma a corrente feminista anti-pornografia, estudos apontam que os fatores que influenciam na criação de uma personalidade violenta residem majoritariamente na infância do agressor, e o desejo por consumir material pornográfico que expressa subordinação da mulher é mais um sintoma que uma causa de desvio de conduta ${ }^{92}$.

Ademais, Ronald Dworkin entende que os argumentos anti-pornografia se baseiam no falacioso princípio de que em nome da igualdade deve-se restringir o direito a livre expressão de determinados gostos particulares, convicções ou preferências subjetivas ${ }^{93}$. Tal pressuposto poderia acarretar em consequências devastadoras para a comunidade política ao abrir precedentes para a censura estatal de conteúdos gráficos, viscerais ou emocionalmente carregados que viessem a ofender minorias ${ }^{94}$. Alicerçada em noções como a primazia do respeito às liberdades negativas e positivas no liberalismo, bem como no entendimento de que a função primordial do Estado é a de garantir condições de igualdade para poder promover o respeito as escolhas individuais de cada um, a retórica dworkiana é aqui sintetizada de forma extremamente simplória e com o objetivo de pincelar o posicionamento liberal contrário as argüições feministas. No entanto, por motivos de coerência com a linha argumentativa deste trabalho, optou-se pelo não aprofundamento no debate contra a posição anti-pornografia.

\footnotetext{
92 “...In spite of MacKinnon's fervent declarations, no reputable study has concluded that pornography is a significant cause of sexual crime: many of them conclude, on the contrary, that the causes of violent personality lie mainly in childhood, before exposure to pornography can have any effect. and that desire for pornography is a symptom rather than a cause of deviance." DWORKIN, Ronald apud. WEST, Caroline. Pornography and Censorship. The Stanford Encyclopedia of Philosophy: $\quad$ Edward N. Zalta. $\quad$ Disponível em: https://plato.stanford.edu/archives/fall2013/entries/pornography-censorship/. Acesso em 07 jun. 2017.

93 “(...) Frightening principle that considerations of equality require that some people not be free to express their tastes or convictions or preferences anywhere". Ibid.

94 "Government could forbid the graphic or visceral or emotionally charged expression of any opinion that might reasonably offend a disadvantaged group. It could outlaw performances of The Merchant of Venice, or films about professional women who neglect their children, or caricatures or parodies of homosexuals in nightclub routines" Ibid.
} 


\section{Olhares jurídicos sobre o pornô no Brasil}

\subsection{O que há de novo na pornografia: alcances e influências inaugurados pela internet}

Em ebulição nos anos oitenta, o debate sobre pornografia e as propostas legislativas de MacKinnon e Dworkin debruçaram-se sobre diferentes panoramas de produção e difusão de seu material. Hoje, o cenário pornô comporta novas configurações, radicalmente alteradas em função da inserção da internet na dinâmica de circulação do material pornográfico. Naturalmente, a web não é a única plataforma pela qual se propaga a pornografia: o mundo pornô conta com uma série de outros meios pelos quais seu material é fornecido, valendo-se também de uma lucrativa produção de filmes pornográficos- inclusive no Brasil ${ }^{95}$. No entanto, é através de websites de acesso imediato e irrestrito ao público que a disseminação e consumo de pornografia alcança níveis espantosos. Vale elucidar alguns deles.

Estatisticamente, afirma-se que sites pornôs possuem mais acessos mensais do que Netflix, Amazon e Twitter juntos ${ }^{96}$. São 4,2 milhões de sites pornográficos disponíveis na web, consubstanciando $12 \%$ de todos os sites de rede mundial, com acesso de 72 milhões de visitantes por mês. Os Estados Unidos, segundo o site TopTenReviews ${ }^{97}$, faturaram cerca de 14 bilhões com pornografia via internet no ano de 2006. Neste ano, entre os vinte países que mais lucraram com o conteúdo adulto na web encontramos o Brasil em $16^{\circ}$ lugar, movimentando aproximadamente 100 milhões de dólares no ano. De acordo com a lista mais recentemente divulgada de top sites pela Alexa, o

\footnotetext{
95 Para este fim, o livro "Nas redes do sexo- os bastidores do pornô brasileiro", lançado em 2010 e escrito pela antropóloga Maria Elvira Benitez, oferece uma reflexão sobre o cinema pornô brasileiro. A autora acompanha todas as etapas de produção de um filme pornográfico, desde o planejamento de suas produções até a confecção e distribuição do material. Informação disponível em: http://www1.folha.uol.com.br/livrariadafolha/2013/11/769426-nas-redes-do-sexo-expoe-detalhesdo-mundo-porno-leia-trecho.shtml. Acesso em 26/05/2017.

Também neste sentido vale destacar o lançamento em vista da Sexflix, plataforma de streaming que contará com a exibição de filmes da produtora Brasileirinhas. Informação disponível em http://www.diariodepernambuco.com.br/app/noticia/viver/2017/05/04/internas_viver,702263/brasi leirinhas-lanca-sexflix-com-filmes-pornos-e-e-notificada-pela-n.shtml. Acesso em 26/05/2017.

${ }^{96}$ Informação extraída do documentário Hot Girls Wanted, lançado em 2015 pela rede Netflix.

${ }^{97}$ Informação disponível em http://www.toptenreviews.com/internet-pornography-statistics/, com estatísticas baseadas em pesquisa realizada no ano de 2016. Acesso em 26/05/2017.
} 
portal xvideos.com figura em $17^{\circ}$ lugar no ranking dos sites mais acessados no Brasil ${ }^{98}$.

A plataforma pornhub insights disponibiliza interessantes dados sobre o acesso ao site pornhub.com ${ }^{99}$ e redtube. com $^{100}$. De acordo com a pesquisa realizada em fevereiro de 2016, o Brasil figurou em $2^{\circ}$ lugar no ranking mundial de acesso ("proportion of traffic") ao portal redtube.com, perdendo apenas para os Estados Unidos. A proporção de usuárias mulheres no site, embora acima da média mundial, soma apenas $33 \%$ entre seus visitantes, tratando-se de material evidentemente destinado ao consumo masculino. Dentre os tópicos mais visitados, a pesquisa de 2016 classificou os tipos "lésbica", "anal" e "jovem" entre os três mais procurados no portal. Os termos mais pesquisados diretamente nesse sentido são "lésbicas", "putinha brasileira", "novinha brasileira anal" e "novinha". Também vale destacar a média de idade entre os visitantes brasileiros do redtube.com: são jovens entre 18 e 24 anos os que mais consumem o material do site ${ }^{101}$. A cifra envolvendo menores de idade parece ainda maior: segundo Gail Dines, ativista anti-pornografia, aproximadamente $90 \%$ dos jovens entre 8 e 16 no mundo já acessaram sites pornôs.

A divulgação do conteúdo pornográfico na internet alastrou-se em proporções massivas. Os sites mencionados acima exibem o que é convencionado como pornô mainstream, ou seja, o conteúdo dominante, de mais fácil, rápido e livre acesso no universo da pornografia. Além de fomentar uma indústria que mobiliza milhares de dólares anualmente, as imagens e vídeos divulgadas pelos sites pornôs podem ser visualizadas em

\footnotetext{
${ }^{98}$ Disponível em http://www.alexa.com/topsites/countries/BR. Acesso em 26/05/2017.

${ }^{99}$ A pesquisa realizada em 2015 situou o Brasil em $8^{\circ}$ lugar no ranking mundial de visitantes diários do pornhub.com.

${ }^{100}$ Disponível em https://www.pornhub.com/insights/redtube-brazil. Acesso em 26/05/2017.

101 "As it turns out, our dear Brazilians are quite the early bloomers. We decided to explore age demographics and noticed that there is a much larger proportion of viewers aged 18-24 in Brazil when compared to the world average. $71 \%$ of Redtube users are millennial-aged compared to $54 \%$ worldwide.” Disponível em https://www.pornhub.com/insights/redtube-brazil. Acesso em 26/05/2017
} 
menos de segundos e sem qualquer tipo de restrição, bastando um clique. E qual é, afinal, o conteúdo transmitido atualmente por estas páginas?

Breves incursões aos sites mais acessados do Brasil demonstram-se suficientes para a constatação de que imagens de mulheres subjugadas, violentadas e objetificadas são amplamente difundidas- sem mesmo que se faça necessária uma busca específica por termos de cunho hardcore. Em 26 de maio de 2017, a visita ao site xvideos.com, o mais visitado do Brasil segundo as estatísticas transcritas acima, contava em sua primeira página com o vídeo em destaque de título "Babalu em papel de puta sendo abusada”. Ainda sem clicar no link, a mera passagem com o mouse por cima da imagem já antecipa em flashs as cenas do filme: uma simulação de estupro grupal envolvendo dois homens e uma mulher. O vídeo, cuja duração é de trinta minutos, apresenta trama na qual uma prostituta é contratada por dois homens que, espantados com o excessivo valor cobrado, decidem encurralála e violentá-la. Enquanto aguardam pela mulher, um dos homens retira uma faca do bolso e diz "ela não sabe o que aguarda por ela, vou bater na cara dela com o facão, assim". Imediatamente após sua chegada, a mulher é ameaçada e afrontada "eu tenho cara de quem paga puta, sua vagabunda?". Ela tem suas pernas e mãos atadas, a boca amordaçada por uma corda e é sistematicamente violentada pelos próximos minutos do filme, enquanto chora e grita. No final, os dois homens ejaculam e a mulher é liberta.

No dia 29 de maio, entre os trending now ${ }^{102}$ do site redtube.com observou-se o vídeo "Gang bang double fisting and ass fucked skinny teen slut". De duração de seis minutos, dois homens realizam o fisting em uma jovem. A prática de fisting na pornografia, abreviação para o termo fist fucking, consiste na inserção da mão ou antebraço na vagina ou ânus da mulher. Nas imagens, os dois homens simultaneamente inserem pênis no ânus e braços na vagina da mulher, alternando entre si. A prática de fisting requer cuidadosas medidas de proteção e higiênicas tendo em vista o alto

102 Trending now ou trending topics são referentes ao assunto ou vídeo do momento, mais comentados ou assistidos. 
risco de transmissão de doenças, especialmente em função das bactérias presentes embaixo das unhas e ao redor das cutículas. Para tanto, o uso de luvas de látex e de lubrificantes é exigido para que se tenha uma prática segura do fisting. Não obstante, em diversos momentos ao longo do vídeo podemos observar algum dos homens, sem identificar qual, inserindo os punhos sem proteção na vagina da mulher. Seu rosto, por sua vez, não aparece no vídeo, e nenhum som é emitido por ela. Logo abaixo da da tela de exibição, um anúncio com objetos amplificadores de orifícios anais e vaginais à venda é exibido.

Práticas anais extremas, como fisting, ass gaping e rosebud ${ }^{103}$ sempre foram comuns entre produtores e adeptos à pornografia sadomasoquista. A veiculação cada vez maior de tais modalidades entre vídeos amadores e de forma gratuita em sites de streaming, no entanto, representam uma tendência nova no mercado pornográfico como um todo ${ }^{104}$. Estudiosos no tema afirmam que, na indústria de filmes, o sexo anal hardcore foi deslocado de uma ceara marginal para uma prática convencional e obrigatória nos enredos. Sheena Shaw, iniciada na pornografia amadora e hoje atriz especializada em anal extremo, aduziu em entrevista que "todo o mundo é pressionado a fazer anal. A cultura nos ensina do que gostar e não gostar" ${ }^{105}$. A esse respeito, a produtora Holly Randall comenta:

\footnotetext{
${ }^{103}$ No gaping anal, a inserção do pênis ou de outro objeto no ânus é forçada a tal ponto que, ao removê-lo, o orifício anal permanece esticado e aberto, podendo ser observado seu interior. Já o rosebud é causado pelo prolapso retal, condição em que as paredes internas do reto entram em colapso e escorregam para fora do ânus, expelindo seu tecido interno e vermelho como uma rosa. Sobre a prática de rosebud, vale a leitura disponível em https://www.vice.com/pt br/article/umbotao-de-rosa-que-cheira-a-merda. Acesso em 28/05/2015.

104 Maria Elvira Dias-Benitez estuda especificamente a produção de filmes pornográficos brasileiros, extravasando a discussão sobre o material disponível em sites na internet. No entanto, para efeitos de reflexão sobre a convencionalização das práticas anais no pornô, vale destacar trecho de sua obra: "Atualmente, o sexo anal não é mais uma simples modalidade da pornografia, confundido-se e entrecruzando-se com a corrente principal, a ponto de ser ele próprio considerado mainstream, fazendo parte do repertório-chave de disposições sexuais. Na rede de produção de filmes pornográficos que pesquiso, fazer sexo anal é atualmente uma obrigação para a mulher que deseje ingressar na carreira ou participar temporariamente desse mundo; uma resposta negativa pode fechar as portas da indústria". BENITEZ, Maria Elvira. Nas Redes do Sexo: bastidores e cenários do pornô brasileiro, 2012, p. 232.

105 Disponível em https://www.vice.com/pt_br/article/um-botao-de-rosa-que-cheira-a-merda. Acesso em 28/05/2015.
} 
Com produções de ponta pressionando para abrir caminho para o conteúdo amador e extreme, criou-se um mercado que eu chamo de Olimpíadas Pornô. Agora é uma questão de quão longe você pode ir: com quantos homens você pode ter sexo em um filme, quantos pênis você pode pôr em seus orifícios, quantas maneiras você pode comer sêmen. Na tentativa de ser o mais inovador, cenários com que eu não poderia nem sonhar se tornam bastante normais. ${ }^{106}$

Tal movimento também é perfeitamente observável na pornografia na web. Verdade é que o vídeo narrado acima, além de constar entre os trendings do dia, contém duas das três palavras mais procuradas no portal segundo as estatísticas: "anal" e “jovem”, convertidas para o inglês. Seu acesso é duplamente facilitado.

No dia 30 de junho de 2017, verificava-se "EDITEDyoung cuties abused 2hours" entre os vídeos mais acessados do site pornhub.com. Tratase de uma compilação de 190 minutos de diferentes vídeos caseiros envolvendo mulheres sendo abusadas, em sua maioria através de sexo oral forçado. Entre eles, destaca-se um. Uma jovem de baixa estatura, sentada e encostada na parede de uma banheira, é filmada por uma câmera que parece escondida. Um homem está de pé diante dela e se aproxima, forçando sua cabeça contra a parede. Em seguida, ele insere seu pênis em sua garganta e força um movimento contínuo para frente, em algum ponto colocando todo o seu órgão dentro da boca da mulher, que tenta se desvencilhar e engasga. A pressão do seu quadril forçando a mulher contra a parede faz com que em algum momento seu rosto fique roxo em razão do sufocamento. Por fim, o homem retira o pênis de sua boca e se masturba, ejaculando no rosto da mulher enquanto ela chora.

O vídeo ressaltado é ilustrativo de uma outra tendência observável na pornografia da internet: o crescente número de vídeos amadores caseiros submetidos a sites pornográficos. O amadorismo no pornô complexifica seu cenário. Não se sabe quem submeteu o vídeo, se houve consentimento em sua divulgação, se são cenas coreografadas por um script ou improvisadas

\footnotetext{
${ }^{106}$ RANDALL, Holly apud. DAU, Erick. A pornografia hoje: as estratégias do capitalismo através do sexo. Ideologia e opressão da mulher. 2014. 133 p. Dissetação (Mestrado em Comunicação e Cultura) - Programa de Pós Graduação em Comunicação e Cultura da Escola de Comunicação da Universidade Federal do Rio ode Janeiro, p. 34.
} 
frente a câmera. Os vídeos caseiros, no momento em que são integram a rede, circulam com a rapidez que é característica da internet, e o gênero amador possui a marca do anonimato. É difícil diferenciar quando se trata de encenação ou material snuff- estupros reais filmados- tradicionalmente comercializados em plataformas virtuais ilícitas como a deepweb.

As cenas descritas acima foram retiradas do conteúdo disponível na primeira página dos sites pornográficos mais visitados do Brasil. São vídeos de destaque do dia que pairam sobre a tela no momento imediato em que o site é aberto. Para visualizá-los, não foi necessária a inserção de termos específicos em chaves de busca que viessem a restringir os vídeos àqueles de conotação mais agressiva: a divulgação mainstream de imagens com o mesmo grau de brutalidade é verificável. No entanto, caso fosse do desejo do consumidor acessar diretamente vídeos de caráter violento, um clique na $\operatorname{tag}^{107}$ abused no site xvideos.com bastaria para que aproximadamente dez mil vídeos envolvendo simulações de mulheres estupradas e abusadas se revelassem ao longo de mais de quarenta páginas de visualização.

Outros gêneros e tags que remetem diretamente a subordinação e violência da mulher também são igualmente de fácil acesso. Entre eles, podemos citar:

A penetração vaginal, oral e anal de mulheres por três ou mais homens ao mesmo tempo; o duplo anal, onde uma mulher é penetrada no ânus por dois homens ao mesmo tempo; o duplo vaginal, quando a vagina é penetrada por dois homens simultaneamente; a prática de gagging, quando o pênis é introduzido na garganta da mulher de forma que ela sufoque (ou, em casos extremos, vomite); ass-tomouth, quando o pênis é retirado do anus da mulher e em seguida introduzido em sua boca, sem lavagem; e bukkake, quando qualquer número de homens ejaculam sobre o corpo, rosto, cabelo, olhos, orelhas ou boca da mulher. Em alguns casos, os homens ejaculam em um copo, e o chamado money shot acontece quando a mulher bebe o sêmen. ${ }^{108}$

\footnotetext{
107 “As tags na internet são palavras que servem justamente como uma etiqueta e ajudam na hora de organizar informações, agrupando aquelas que receberam a mesma marcação, facilitando encontrar outras relacionadas." Definição disponível em https://www.tecmundo.com.br/navegador/2051-oque-e-tag-.htm. Acesso em 26/05/2017.

${ }^{108}$ DAU, Erick. A pornografia hoje: as estratégias do capitalismo através do sexo. Ideologia e opressão da mulher. 2014. 133 p. Dissetação (Mestrado em Comunicação e Cultura) - Programa de Pós Graduação em Comunicação e Cultura da Escola de Comunicação da Universidade Federal do Rio ode Janeiro.
} 
Imagens de bukkake e money shot são visualmente identificadas como aquelas frequentemente invocadas nas abas laterais de sites pornográficos para atrair a atenção do consumidor a algum tipo de propaganda. Também vale acrescentar à lista o verbal-abuse, gênero de vídeo e tag no qual a mulher é xingada, humilhada e discriminada antes e durante a prática de sexo oral forçado. Para Gail Dines, todas essas modalidades de expressão do pornô constroem a imagem de uma mulher que deseja ser sexualmente explorada ${ }^{109}$.

O número maciço de jovens que mundial e nacionalmente frequentam sites pornô na web sugestiona a existência de um algum tipo de instrução sexual construída também por meio da pornografia. Nesse sentido, em estudo dirigido por Carolina Bouchardet Dias e orientado pela professora Adriana Vidal $^{110}$ são avaliados os impactos da pornografia na saúde de adolescentes. Os dados analisados são oriundos da pesquisa STIR (Safeguarding Teenage Intimate Relashionships), desenvolvida por pesquisadores da Universidade de Bristol e Central Lancanshire e centrada em jovens da Inglaterra, Noruega, Chipre, Bulgaria e Italia. Em termos gerais, a pesquisa STIR organizou a incidência de cada tipo de violência interpessoal- online, emocional, física e sexual- por país e gênero. Uma breve e superficial passagem pelos dados inicias já aponta assustadores índices de violência sexual sofrida por jovens dentro de seus próprios relacionamentos; $17 \%$ a $41 \%$ entre as meninas, e $9 \%$ a $25 \%$ entre os meninos. Na investigação sobre atitudes concernentes a

\footnotetext{
109 "In porn, sex is framed as not just consensual but as something that the woman seeks out because she loves to be sexually used. This also is a method for lessening any guilt the user may feel as he can reassure himself that she is not being hurt, or if she is, it is what she wants. Take for example the description of "Gauge" on the site Ass Plundering: "Gauge gives a new meaning to the world whore. Any less than 2 guys at once means she won't be satisfied. Her tight holes need to be ravaged by big cocks at the same time for her to have fun". The imagens surrounding this text show how Gauge being orally, vaginally, and anally penetrated by three men at the same time. One of the images shows a red, raw and swollen anus while others show her face contorted as she is supposedly having an orgasm. The images and the written text together, as well as the movie, which presents her begging for more, collude to suduce the viewer into believing that no matter how cruelly her body is being treated, she belongs to a special breed of women that enjoy sexual mistreatment. Similarly, on the British Bukkake site, the text reads 'If you like horny bitches that like to drench themselves in hot jizz, this is the site for you. These girls know how to do it up right and you're guaranteed to get off when you see their dripping faces full of cum."'. DINES, Gail. How has porn hijacked our sexuality. $3^{\mathrm{a}}$ ed.. Boston: Beacon Press, 2010. 204 p.

${ }^{110}$ Adriana Vidal é professora da Pontifícia Universidade Católica do Rio de Janeiro.
} 
violência de gênero, os pesquisadores questionaram os jovens a respeito de três afirmativas: (1) para trabalhos mais importantes é melhor escolher um homem do que uma mulher, (2) mulheres provocam os homens sexualmente e depois reclamam sobre a atenção que conseguem e (3) às vezes é aceitável um homem bater em uma mulher se ela for infiel. A cada afirmativa, os jovens deviam apontar seu grau de concordância em uma escala de 1 a 5 . A maior pontuação, para os analistas, era considerada a pior atitude em relação a gênero. Em todos os países estudados foi verificado que meninos estariam sensivelmente mais inclinados a apresentarem más atitudes de gênero do que meninas. No exame individual das três afirmações, as pontuações mais altas concentraram-se na segunda afirmação. Sugere-se, a partir do resultado obtido, que ainda circula com naturalidade entre os jovens o postulado de que mulheres são responsáveis pela violência sexual por elas sofrida, pensamento associável ao poder e influência da pornografia na educação sexual.

Nesse sentido, diante os dados colhidos, Carolina Dias afirma que a pornografia mainstream violenta, compreendida através da concepção de MacKinnon e Dworkin, trabalha a favor da normalização de comportamentos agressivos dirigidos as mulheres. Ainda que não intencionalmente- vale lembrar a noção de intrusão mental insconciente cunhada por MacKinnon- o consumo de pornografia pode vir a gerar uma dessensibilização ao que realmente é a violência infringida às mulheres ${ }^{111}$. Embora não se saiba em que medida ou precisamente de que forma, os dados demonstrados anunciam alguma de correlação razoável extremamente provável entre o consumo de pornografia e a educação sexual.

Allison Pearson, colunista do jornal britânico The Telegraph, escreveu sobre as alterações provocadas na adolescência pela popularização e massificação do acesso ao conteúdo pornográfico disponível na internet. Pearson reporta o percentual crescente de taxas de ansiedade atingindo meninas entre 11 e 16 anos, aduzindo que as questões geradores

\footnotetext{
${ }^{111}$ Disponível em: http://www.puc-rio.br/pibic/relatorio_resumo2016/relatorios_pdf/ccs/DIR/DIRCarolina Dias.pdf. Acesso em 01/05/2017.
} 
predominantes são de ordem sexual. A jornalista também nota que conflitos travados durante o momento de iniciação sexual dos jovens parecem cada vez mais presente s na experiência clínica de psicanalistas britânicos. Em especial, observa-se entre jovens homens e mulheres o sentimento de pressão em desempenhar determinados papeis ou atos sexuais. Nesse sentido, Pearson compartilha a experiência de uma psicanalista especializada na clínica adolescente, que narra cada vez mais receber pacientes adolescentes fisicamente machucas ao praticarem sexo anal por pressão ${ }^{112}$.

Verdade é que o panorama estatístico apresentado acima, seja a respeito da precisão sobre o consumo de pornografia online ou sobre a influência do pornô na educação sexual dos jovens, apenas sugere uma conexão de causa-efeito entre pornografia e reprodução da violência de gênero. Esta ligação, sabe-se, não pode ser dada como fato. A literatura e pesquisa sobre o tema, especialmente no Brasil, não levam a uma base empírica mínima para poder se afirmar com firmeza científica qual é medida da influência pornografia nas dinâmicas relacionais de gênero. Além disso, assume-se a multiplicidade de fatores sociais que influenciam no comportamento do sujeito, bem como a complexidade e a singularidade no processo de articulação interior desses fatores. Entender a pornografia como causa original automática do desejo violento de subordinação da mulher seria negligenciar toda a riqueza de elementos sociais e históricos, pessoais e psicológicos que compõem a subjetividade do indivíduo.

No entanto, é possível que o consumo de pornografia leve a mimetização de um comportamento sexual violento, e é provável essa relação seja de causalidade, ou, no mínimo, de retroalimentação. Em levantamento mais recente do IPEA, feito com base nos dados de 2011 do Sistema de Informações de Agravo de Notificação do Ministério da Saúde (Sinan), identificou-se que o Brasil possui um caso de estupro notificado a cada 11 minutos, contando com uma significativa margem de subnotificação. Estima-

\footnotetext{
${ }^{112}$ Disponível em: http://www.telegraph.co.uk/women/mother-tongue/11554595/Pornography-haschanged-the-landscape-of-adolescence-beyond-all-recognition.html. Acesso em 02/06/2017.
} 
se um total de 527 mil pessoas estupradas por ano no país. Dos casos notificados, 89\% são vítimas mulheres. Segundo o Ipea, 70\% dos estupros são cometidos por parentes, namorados ou conhecidos da vítima. Os estupros no Brasil são majoritariamente praticados contra crianças e adolescentes, também contando com uma percentagem de $70 \%$ do total registrado. Cerca de $15 \%$ desses estupros registrados envolveram dois ou mais agressores, sendo o estupro coletivo mais comum entre adolescentes. $67 \%$ da população brasileira tem medo de ser vítima de agressão sexual, e esse percentual sobe para $90 \%$ entre mulheres ${ }^{113}$. Em um país com aterrorizantes taxas de violação sexual contra a mulher, a necessidade de se combater as múltiplas causas da violência é- ou deveria ser- pauta de urgência na agenda pública. A pornografia mainstream, em assustadora parcela de seu conteúdo, simultaneamente institui e reforça um padrão de sexualidade impregnada de referências simbólicas e explícitas à objetificação da mulher. Através dessas imagens, ao mesmo tempo se instaura, encena, encarna e reproduz a violência. Desta forma, o material pornográfico, enquanto potencial causador e subproduto desse cenário, deveria ser minimamente debatido no quadro político brasileiro. E quais são os enfoques estatais sobre a pornografia atualmente?

\subsection{O cenário legal atual da pornografia}

Através de um extenso panorama, o Instituto da Medicina Social da Universidade do Estado do Rio de Janeiro documentou em 2004 o estado dos direitos e políticas sexuais no Brasil desde $1998^{114}$ até então. Embora significativas políticas contra a violência de gênero tenham sido geradas desde então, incluindo a promulgação da lei Maria da Penha ( $\left.\mathrm{n}^{\circ} 11.340\right)$ no ano de 2006, o quadro legal envolvendo especificamente o tema da

\footnotetext{
113 Dados disponíveis em http://www.ipea.gov.br/portal/index.php?option=com content $\&$ view $=$ article $\& i d=21849 \&$ catid=8 \&Itemid=6. Acesso em 02/06/2017.

114 Disponível em http://www.clam.org.br/uploads/conteudo/doccompleto.pdf. Acesso em 02/06/2017.
} 
pornografia permanece quase intacto. A contemplação da legislação brasileira com relação a pornografia tange apenas dois de seus aspectos: a pornografia infantil, criminalmente tipificada pelo Estatuto da Criança e do Adolescente, e a pornografia de vingança, que, embora não disponha de nenhum diploma legal especialmente destinado a sua consideração, já possui no Judiciário e na doutrina discussões a seu respeito.

A preocupação do constituinte de 1988 com a garantia dos direitos de crianças e adolescentes levou a formulação do art. 277, que institui ser obrigação da família, da sociedade e do Estado colocá-los "a salvo de toda forma de negligência, discriminação, exploração, violência, crueldade e opressão", destacando em seu $\S^{\circ}$ a punição ao abuso, à violência e à exploração sexual deste grupo vulnerável. A disposição constitucional, no entanto, só obteve reflexo expresso no Estatuto da Criança e do Adolescente (lei $\mathrm{n}^{\mathrm{o}} 8.069 / 90$ ) no ano de 2000, quando a lei 9.975/200 acrescentou ao texto original o art. 244-A, estabelecendo penas entre quatro e dez anos de reclusão para quem "submeter criança ou adolescente (...) à prostituição ou exploração sexual”. Em 2003, a lei 10.764 trouxe nova alteração ao ECA, ampliando a dimensão conceitual de exploração sexual a ser proibida. Por fim, a lei $\mathrm{n}^{\mathrm{o}} 11.829$ de 2008 veio a alterar profundamente o Estatuto da Criança e do Adolescente quanto a proibição de pornografia infantil, trazendo novos dispositivos para aprimorar o combate à produção, venda $\mathrm{e}$ distribuição de seu conteúdo, bem como criminalizar a aquisição e a posse deste material e outras condutas relacionadas à pedofilia na internet. Novas redações foram conferidas ao art. 240, 241 e 241-A do ECA ${ }^{115}$. A importância

\footnotetext{
115 Art. 240. Produzir, reproduzir, dirigir, fotografar, filmar ou registrar, por qualquer meio, cena de sexo explícito ou pornográfica, envolvendo criança ou adolescente:

Pena - reclusão, de 4 (quatro) a 8 (oito) anos, e multa.

$\S 1^{\circ}$ Incorre nas mesmas penas quem agencia, facilita, recruta, coage, ou de qualquer modo intermedeia a participação de criança ou adolescente nas cenas referidas no caput deste artigo, ou ainda quem com esses contracena.
}

Art. 241. Vender ou expor à venda fotografia, vídeo ou outro registro que contenha cena de sexo explícito ou pornográfica envolvendo criança ou adolescente:

Pena - reclusão, de 4 (quatro) a 8 (oito) anos, e multa. 
de efetuar tais transformações é decorrência direta da necessidade de se reestruturar a legislação de acordo com a nova ordem principiológica constitucional e com os diplomas internacionais de direitos humanos ratificados pelo ordenamento interno. Percebe-se que o legislador, seja nas reformas de 2003 ou de 2008, buscou instituir saídas legais capazes de evitar que a interpretação restritiva dos tipos penais não obstruísse o combate a pornografia infantil com o alastramento da rede mundial de computadores e a facilitação na divulgação do material proibido.

O fenômeno da pornografia de vingança, tradução da expressão inglesa "revenge porn", por sua vez representa toda atividade de divulgação de material sexualmente gráfico, íntimo ou privado de uma pessoa sem a sua autorização em qualquer meio de divulgação, sobretudo na internet e nas mídias sociais. O aumento exponencial do número de casos de revenge porn, majoritariamente movidos por parceiros ou ex-parceiros da vítima, levaram a uma considerável movimentação legislativa para tratar do tema. A divulgação de fotos, vídeos e outros materiais com teor sexual sem o consentimento dos envolvidos é comumente interpretada pela jurisprudência como caso de difamação ou injúria, delitos previstos respectivamente nos artigos 139 e 140 do Código Penal ${ }^{116}$. A depender da particularidade do caso,

Art. 241-A. Oferecer, trocar, disponibilizar, transmitir, distribuir, publicar ou divulgar por qualquer meio, inclusive por meio de sistema de informática ou telemático, fotografia, vídeo ou outro registro que contenha cena de sexo explícito ou pornográfica envolvendo criança ou adolescente:

Pena - reclusão, de 3 (três) a 6 (seis) anos, e multa.

$\S 1^{\circ}$ Nas mesmas penas incorre quem:

I - assegura os meios ou serviços para o armazenamento das fotografias, cenas ou imagens de que trata o caput deste artigo;

II - assegura, por qualquer meio, o acesso por rede de computadores às fotografias, cenas ou imagens de que trata o caput deste artigo.

Art. 241-B. Adquirir, possuir ou armazenar, por qualquer meio, fotografia, vídeo ou outra forma de registro que contenha cena de sexo explícito ou pornográfica envolvendo criança ou adolescente: Pena - reclusão, de 1 (um) a 4 (quatro) anos, e multa."

Disponível em http://www.planalto.gov.br/ccivil 03/_ato2004-2006/2006/lei/111340.htm. Acesso em 02/06/2017.

116 Da redação do Código Penal, extrai-se:

Art. 139 - Difamar alguém, imputando-lhe fato ofensivo à sua reputação:

Pena - detenção, de três meses a um ano, e multa.

Art. 140 - Injuriar alguém, ofendendo-lhe a dignidade ou o decoro:

Pena - detenção, de um a seis meses, ou multa. 
a doutrina também considera a possibilidade de aplicação do art. $21^{117}$ do Marco Civil da Internet, lei $\mathrm{n}^{\mathrm{o}} 12.965$ de 2014, criada com o objetivo de regulamentar o território cibernético. Aqui, a vítima pode requisitar ao provedor a retirada de material íntimo divulgado sem a necessidade recorrer a juízo. Também com relação a pornografia de vingança tramitam alguns projetos de lei nas casas legislativas. Entre eles, destaca-se o PL n 6.630/2013, de autoria do deputado federal Romário (PSB/RJ), que visa criar um novo tipo penal para a conduta a pornografia de vingança ${ }^{118}$.

Nota-se que a discussão sobre pornografia no Legislativo brasileiro não tange minimamente o debate abordado neste trabalho. A proibição da pornografia infantil, sua produção, comercialização, distribuição e aquisição, surge no âmbito específico da rede de tutela especial da criança e do adolescente; seria possível aproximar as discussões entre a situação de vulnerabilidade que se pressupõe da criança e da mulher em um contexto de desigualdade de gênero, mas certamente trataria de complexo debate, e não caberia discuti-lo neste trabalho. Já acerca da pornografia de vingança, o avanço na produção doutrinária a seu respeito e as mobilizações legislativas no sentido de sua coibição são movimentos indissociáveis de um debate sobre poder e violência nas relações de gênero. Nesse sentido, é possível identificar pontos de conexão entre o enunciado deste trabalho e o revenge porn.

Disponível em http://www.planalto.gov.br/ccivil_03/decreto-lei/Del2848compilado.htm. Acesso em 02/06/2017.

${ }^{117}$ Art. 21. O provedor de aplicações de internet que disponibilize conteúdo gerado por terceiros será responsabilizado subsidiariamente pela violação da intimidade decorrente da divulgação, sem autorização de seus participantes, de imagens, de vídeos ou de outros materiais contendo cenas de nudez ou de atos sexuais de caráter privado quando, após o recebimento de notificação pelo participante ou seu representante legal, deixar de promover, de forma diligente, no âmbito e nos limites técnicos do seu serviço, a indisponibilização desse conteúdo.

Parágrafo único. A notificação prevista no caput deverá conter, sob pena de nulidade, elementos que permitam a identificação específica do material apontado como violador da intimidade do participante e a verificação da legitimidade para apresentação do pedido.

Disponível em: http://www.planalto.gov.br/ccivil_03/ato2011-2014/2014/lei/112965.htm. Acesso em 03/06/2017.

${ }^{118}$ A respeito das aplicações legais possíveis aos casos de pornografia de vingança, recomenda-se a leitura do trabalho "Pornografia de Vingança: Contexto Histórico-Social e Abordagem no Direito Brasileiro", de Victoria Buzzi, estudante da Universidade Federal de Santa Catarina. 
Ainda assim, acredito que a associação entre os temas se dê predominantemente em função da inserção de ambos no mesmo eixo de debate: a violação sexual e íntima da mulher em uma conjuntura machista e patriarcal. A pornografia de vingança, no entanto, não abarca a abrangência da problemática envolvendo a pornografia como um todo; talvez este possa ser considerado um gênero, do qual aquele é um desdobramento ou subespécie. Em diversos sites, conteúdo oriundo de revenge porn é disponibilizado para o público consumidor. O revenge porn, no entanto, é um ato direto de quebra do consentimento da mulher através da divulgação de conteúdo de teor íntimo e sexual, com o intuito de puni-la e humilha-la. $\mathrm{O}$ ferimento da ordem íntima interior da mulher, motivado pelo dolo presente na atitude, já é por si só suficiente para figurar em tipos penais preexistentes como a injúria e a difamação. Todavia, como foi dissertado neste trabalho, a discussão sobre pornografia se vale de um abordagem substantiva da autonomia mulher. A ausência de consentimento é condição sine qua non para a configuração do revenge porn; o debate sobre a influência da pornografia na internalização de padrões sexuais violentos ultrapassa a verificação do consentimento em sua produção. A presença do consentimento expresso da mulher na adesão a um script pornográfico violento não encerra o debate sobre pornografia. Para problematiza-la, a internalização de normas de caráter opressivo na constituição das preferências subjetivas de uma mulher é pressuposta.

Posto isso, conclui-se que a produção legislativa brasileira não assume qualquer olhar crítico sobre a pornografia enquanto potencial agente na conformação da realidade brutal que vivemos hoje. O Brasil ocupa posição entre os cinco países que mais consomem pornografia na web no mundo, e o conteúdo imediatamente disponível nos sites mais acessados do país reitera a percepção de uma mulher sexualmente explorada, violentada e objetificada. A conexão parece lógica, mas o debate na agenda pública nacional não a acompanha. 


\subsection{Proposições reflexivas sobre o tema}

Alguns nortes podem guiar a discussão jurídica a respeito da pornografia. A professora Raisa Duarte da Silva Ribeiro, em estudo sobre o tema, sugere que a presença da violência de gênero no conteúdo pornográfico mainstream pode ser notada através da sua compatibilidade com a definição de violência contra a mulher presente na Lei $\mathrm{n}^{\mathrm{o}}$ 11.340/06. Desta forma, a autora propõe uma extensão do conceito de violência doméstica apresentado pela Lei Marinha da Penha à violência de gênero ${ }^{119}$. De acordo com a lei,

Art. 7o São formas de violência doméstica e familiar contra a mulher, entre outras:

I - a violência física, entendida como qualquer conduta que ofenda sua integridade ou saúde corporal;

II - a violência psicológica, entendida como qualquer conduta que lhe cause dano emocional e diminuição da auto-estima ou que lhe prejudique e perturbe o pleno desenvolvimento ou que vise degradar ou controlar suas ações, comportamentos, crenças e decisões, mediante ameaça, constrangimento, humilhação, manipulação, isolamento, vigilância constante, perseguição contumaz, insulto, chantagem, ridicularização, exploração e limitação do direito de ir e vir ou qualquer outro meio que lhe cause prejuízo à saúde psicológica e à autodeterminação;

III - a violência sexual, entendida como qualquer conduta que a constranja a presenciar, a manter ou a participar de relação sexual não desejada, mediante intimidação, ameaça, coação ou uso da força; que a induza a comercializar ou a utilizar, de qualquer modo, a sua sexualidade, que a impeça de usar qualquer método contraceptivo ou que a force ao matrimônio, à gravidez, ao aborto ou à prostituição, mediante coação, chantagem, suborno ou manipulação; ou que limite ou anule o exercício de seus direitos sexuais e reprodutivos;

IV - a violência patrimonial, entendida como qualquer conduta que configure retenção, subtração, destruição parcial ou total de seus objetos, instrumentos de trabalho, documentos pessoais, bens, valores e direitos ou recursos econômicos, incluindo os destinados a satisfazer suas necessidades;

V - a violência moral, entendida como qualquer conduta que configure calúnia, difamação ou injúria.

A autora aduz que a pornografia mainstream perpetua, ainda que de forma sutil, todas as modalidades de violência presentes na definição legal. Certamente, tomando-se os três exemplos de vídeos destacados entre os mais acessados dos sites pornhub.com, xvideos.com e redtube.com, em dias

119 RIBEIRO, Raisa Duarte. Violência de gênero e pornografia. Disponível em: https://www.youtube.com/watch?v=du2vmxieEOk. Acesso em 03/06/2017. 
diferentes, pode-se perceber a presença de pelos menos quatro entre as cinco modalidades descritas. A Lei Maria da Penha, em sua estrutura e dispositivos, dialoga com uma realidade na qual homens e mulheres não possuem o mesmo grau de poder de fato. Partindo-se se pressuposto, busca-se alinhar a discrepância entre gêneros através de medidas afirmativas. Faz-se interessante, para os mesmos fins reflexivos, citar a motivação por trás da Lei Maria da Penha. Os seguintes itens da Exposição de Motivos do projeto de lei que gerou a lei dispõem que:

6. O projeto delimita o atendimento às mulheres vítimas de violência doméstica e familiar, por entender que a lógica da hierarquia de poder em nossa sociedade não privilegia as mulheres. Assim, busca atender aos princípios de ação afirmativa que têm por objetivo implementar "ações direcionadas a segmentos sociais, historicamente discriminados, como as mulheres, visando a corrigir desigualdades e a promover a inclusão social por meio de políticas públicas específicas, dando a estes grupos um tratamento diferenciado que possibilite compensar as desvantagens sociais oriundas da situação de discriminação e exclusão a que foram expostas".

7. As iniciativas de ações afirmativas visam "corrigir a defasagem entre o ideal igualitário predominante e/ou legitimado nas sociedades democráticas modernas e um sistema de relações sociais marcado pela desigualdade e hierarquia". Tal fórmula tem abrigo em diversos dispositivos do ordenamento jurídico brasileiro precisamente por constituir um corolário ao princípio da igualdade.

8. A necessidade de se criar uma legislação que coíba a violência doméstica e familiar contra a mulher, prevista tanto na Constituição como nos tratados internacionais dos quais o Brasil é signatário, é reforçada pelos dados que comprovam sua ocorrência no cotidiano da mulher brasileira.

12. É contra as relações desiguais que se impõem os direitos humanos das mulheres. $O$ respeito à igualdade está a exigir, portanto, uma lei específica que dê proteção e dignidade às mulheres vítimas de violência doméstica. Não haverá democracia efetiva e igualdade real enquanto o problema da violência doméstica não for devidamente considerado. Os direitos à vida, à saúde e à integridade física das mulheres são violados quando um membro da família tira vantagem de sua força física ou posição de autoridade para infligir maus tratos físicos, sexuais, morais e psicológicos.

13. A violência doméstica fornece as bases para que se estruturem outras formas de violência, produzindo experiências de brutalidades na infância e na adolescência, geradoras de condutas violentas e desvios psíquicos graves.

15. $\mathrm{O}$ artigo $5^{\circ}$ da proposta de Projeto de Lei define violência doméstica e familiar contra a mulher como qualquer ação ou conduta baseada na relação de gênero, que cause morte, dano ou sofrimento físico, sexual ou psicológico. É importante ressaltar que a Convenção de Belém do Pará possui objeto mais amplo, 
considerando a violência ocorrida no âmbito público e privado. Para os fins desta proposta, e de forma a conferir-lhe maior especificidade, somente foi considerada a violência ocorrida no âmbito privado. Cabe especial atenção a um conceito basilar previsto na proposta: a relação de gênero. A violência intra-familiar expressa dinâmicas de poder e afeto, nas quais estão presentes relações de subordinação e dominação.

16. As desigualdades de gênero entre homens e mulheres advêm de uma construção sócio-cultural que não encontra respaldo nas diferenças biológicas dadas pela natureza. Um sistema de dominação passa a considerar natural uma desigualdade socialmente construída, campo fértil para atos de discriminação e violência que se "naturalizam" e se incorporam ao cotidiano de milhares de mulheres. As relações e o espaço intra-familiares foram historicamente interpretados como restritos e privados, proporcionando a complacência e a impunidade. (grifou-se)

A análise da ratio legis, em especial a partir dos termos grifados, alarga o horizonte comparativo entre pornografia e violência doméstica. Parece que os postulados informadores do sentido da Lei Maria da Penha podem ser aplicados à temática deste trabalho, especialmente se há concordância com o argumento de MacKinnon segundo o qual a pornografia é uma prática discursiva constitutiva. Seu caráter atuante na conformação de uma realidade injusta e violenta para a mulher indica a urgência no seu tratamento como questão social e política a ser pensada.

Se a pornografia mainstream, ou ao menos parte significativa dela, apresenta como sexualmente excitante um conteúdo impregnado de violência contra a mulher, não poderia ser ela entendida como agente operante de um sistema que naturaliza condutas de dominação? Se há em nossa sociedade uma lógica hierarquizante de poder que desprivilegia mulheres, também não pode ser a pornografia, com tudo o que foi demonstrado acima, um meio através do qual se endossa a desigualdade? A criação da lei Maria da Penha partiu da necessidade de se criar uma legislação que coibisse a violência de gênero em função dos dados que comprovam sua existência. Não seria essa premissa também cabível a pornografia?

Faz-se necessário pontuar que, aqui, não se compreende a violência doméstica e a violência decorrente da pornografia como fenômenos iguais, reconhecendo que ambas possuem formatos e alcances absolutamente distintos. A proposta ao se traçar um paralelo comparativo não é a de 
uniformizá-las enquanto prática, ou sugerir que o combate as duas deve ser realizado da mesma maneira. A proposição é refletir sobre a possibilidade de que os mesmos pressupostos que levaram a criação da lei Maria da Penha também levem ao entendimento da pornografia como uma questão política de ordem pública, a ser deliberada enquanto tal.

Iluminar um debate obscurecido pelo tabu é imprescindível. Enquanto a pornografia parece ser invariavelmente designada a esfera da intimidade privada de seu consumidor, inadequada ao debate público como já o foi em um cenário retrógrado, é imperioso atraí-la para a esfera política. Com a deliberação abre-se caminho para a promoção de medida aptas a desconstruir um cenário de desigualdade. "Se a pornografia machuca mulheres agora, não é necessário que se faça algo sobre isso?"120.

\footnotetext{
120 'If pornography hurts women now, doesn't something need to be done about it? If women if hurt in making pornography, doesn't something need to be done? If pornography is used to choreograph and execute rape, incest, battery and forcing women into prostitution, doesn't it something need to be done? If pornography actually creates attitudes and behaviors of bigotry and aggression against women, as many laboratory studies demonstrate, doesn't something need to be done? If pornography causes rape, or sexualized torture, or increases sadism against women, or plays a role in serial murders, or contributes substantially to legitimizing violence against women, isn't it important to do something about pornography? Ir pornography spreads woman hating and rape as mass entertainment, how can feminists ignore or be indifferent to it as a political issue of equality?" MACKINNON, Catharine. Only Words. Harvard: Harvard University Press. 1993, p. 72.
} 


\section{Considerações Finais}

Ainda que o cenário politico brasileiro apresente um vácuo no que tange a discussão sobre pornografia, não se considera prudente transportar a proposta legislativa de MacKinnon e Dworkin para o Direito pátrio. O ordenamento norte-americano possui não só uma modelagem legal, mas também uma cultura jurídica radicalmente diversa da brasileira. Os textos normativos elaborados por MacKinnon e Dworkin, portanto, dificilmente seriam passíveis de tradução direta capaz de fazê-los caber na ordem interna brasileira. Sabe-se que a discussão sobre pornografia incita um complexo debate em matéria constitucional. Nem mesmo ela poderia ser deslocada dos argumentos de MacKinnon para o sistema pátrio nos mesmo moldes.

O mesmo país que apresenta alarmantes estatísticas de violência contra a mulher contém um dos maiores numerous de consumidores de pornografia no mundo- e, como se pôde perceber, o conteúdo mainstream não só fácil quanto frequentemente acessado apresenta expressões de subordinação, objetificação e humilhação do feminino. Como pontua MacKinnon, a pornografia tem a função de excitar seu consumidor, de provocá-lo desejo. Se o que é exibido como excitante é um conteúdo de dominação, é provável que padrões de sexualidade violenta sejam internalizados de alguma forma, ou que o consumidor deseje reproduzir o que assistiu e causou-lhe prazer.

Os videos descritos neste terceiro capítulo, disponíveis nos sites pornográficos mais acessados do Brasil, naturalmente foram escolhidos com o propósito de carregar o argumento condutor desta análise. Contudo, como dissertado anteriormente, não foi necessário buscá-los através de termoschave específicos como extreme ou hardcore- o que, ainda assim, não retiraria o caráter crítico da sua presença ali. Tratavam-se de videos disponíveis nas primeiras páginas do site, figurando entre os mais assistidos. Não se pretende, com isso, alegar que tudo o que se consome na pornografia da internet faz referência direta ao abuso sexual. No entanto, se a mera presença deste conteúdo nas páginas já se demonstra suficientemente 
problemática, que dirá a sua posição privilegiada no ranking entre mais assistidos.

Neste sentido, almejando um denominador democrático, este trabalho utilizou-se da perspectiva crítica de MacKinnon e Dworkin sobre a pornografia para chamar atenção a uma lacuna na discussão política. Se levarmos em conta a razão legal da lei Maria da Penha, através da exposição de seus motivos, podemos refletir sobre a equivalência não em relação a substância da violência envolvendo cada um dos temas, mas a respeito da importância em se conferir destaque aos dois em um contexto de busca por igualdade entre homens e mulheres. Enquanto a violência doméstica foi regulada e coibida, a violência promovida através e em decorrência da pornografia resta silenciada.É necessário escutar seus gritos. 


\section{Bibliografia}

BERCHT, Gabriela. Pornografia e atos de fala: o debate entre Judith Butler e Catharine MacKinnon. Porto Alegre. 2016. 61 p. Monografia (Graduação em Filosofia) - Departamento de Filosofia da Universidade Federal do Rio Grande do Sul.

BIROLI, Flavia. Agentes imperfeitas: contribuições do feminismo para a análise da relação entre autonomia, preferências e democracia. Revista Brasileira de Ciência Política. Brasília, n. 9, p. 7-38, set./dez. 2012.

BIROLI, Flavia; MIGUEL, Luis Felipe. Teoria politica feminista: textos centrais. $2^{\mathrm{a}}$ ed.. São Paulo: Editora Horizonte, 2013. 376 p.

BODIN DE MORAES, Maria Celina; DALSENTER, Thamis. A autonomia existencial nos atos de disposição do próprio corpo. Revista Pensar. Fortaleza, n. 3, p. 779-818, set./dez. 2014.

BUZZI, Vitória de Macedo. Pornografia de Vingança: contexto históricosocial e abordagem no direito brasileiro. 2015. 111 p. Florianópolis. Monografia (Graduação em Direito) - Departamento de Direito da Universidade Federal de Santa Catarina.

CITTADINO, Gisele. Pluralismo, direito e justiça distributiva: elementos da filosofia constitucional contemporânea. $4^{\mathrm{a}}$ ed.. Rio de Janeiro: Lumen Juris, 2009. 246 p.

CORNELL, Drucilla. Feminism and Pornography. Oxford: Oxford University Press. 2000, 688 p.

DAU, Erick. A pornografia hoje: as estratégias do capitalismo através do sexo. Ideologia e opressão da mulher. 2014. 133 p. Dissetação (Mestrado em Comunicação e Cultura) - Programa de Pós Graduação em Comunicação e Cultura da Escola de Comunicação da Universidade Federal do Rio ode Janeiro.

DIAS, Carolina Bouchardet. Impactos da pornografia na saúde dos adolescentes: uma análise a partir dos direitos fundamentais. Disponível em http://www.pucrio.br/pibic/relatorio_resumo2016/relatorios_pdf/ccs/DIR/DIRCarolina Dias.pdf. Acesso em 07 jun. 2017.

DINES, Gail. How has porn hijacked our sexuality. $3^{\mathrm{a}}$ ed.. Boston: Beacon Press, 2010. 204 p. 
DWORKIN, Andrea. Pornography: Men possessing women. Nova Iorque: G. P. Putnam's Sons. 1981, 300 p.

DWORKIN, Andrea. Intercourse. $2^{\mathrm{a}}$ ed.. Nova Iorque: Basic Books. 2007, $352 \mathrm{p}$.

DWORKIN, Andrea; MACKINNON, Catharine. Pornography and Civil Rights: A new day for women's equality. Nova Iorque: Organizing Against Pornography: A Resouce Center for Education and Action. 1988, 143 p.

MACKINNON, Catharine. Desejo e Poder. In: BIROLI, Flavia; MIGUEL, Luis Felipe (Org). Teoria política feminista: textos centrais. São Paulo: Editora Horizonte, 2013. p. 231-250.

MACKINNON, Catharine. Not a moral Issue. In: CORNELL, Drucilla. Feminism and Pornography. Oxford: Oxford University Press. 2000.

MACKINNON, Catharine. Only Words. Harvard: Harvard University Press. 1993, 152 p.

MACKINNON, Catharine. Toward a Feminist Theory of State. $2^{\mathrm{a}}$ ed.. Harvard: Harvard University Press. 1991, 350 p.

MACKINNON, Catharine. The Sexual Politics of the First Amendment. Cambridge: Harvard University Press, 1987.

MILL, Stuart. Sobre a Liberdade. In: WEFFORT, Francisco C. (Org). Os Clássicos da Política. 10ª ed.. São Paulo: Editora Ática. 2001, 144 p.

OLIVEIRA, Adriana Vidal de. A Constituição da Mulher Brasileira: uma análise dos estereótipos de gênero na Assembleia Constituinte de 1987-1988 e suas consequências no texto constitucional. Rio de Janeiro. 2012. 465 p. Tese (Doutorado em Direito) - Programa de Pós-Graduação em Direito da PUC-Rio.

PEARSON, Allison. Pornography has changed the landscape of adolescence beyond all recognition. Telegraph. Disponível em: http://www.telegraph.co.uk/women/mother-tongue/11554595/Pornographyhas-changed-the-landscape-of-adolescence-beyond-all-recognition.html. Acesso em: 07 jun. 2017.

PATEMAN, Carole. Críticas feministas à dicotomia público/privado. In: BIROLI, Flavia; MIGUEL, Luis Felipe (Org). Teoria política feminista: textos centrais. São Paulo: Editora Horizonte, 2013. p. 55-79 
PATEMAN, Carole. O contrato sexual. São Paulo: Ed. Paz e Terra.1988, 276 p.

Pornhub Team. Redtube \& Brazil, 2016. Disponível em: https://www.pornhub.com/insights/pornhub-brazil. Acesso em 07 jun. 2017.

Pornhub Team. Redtube \& Brazil, 2016. Disponível em: https://www.pornhub.com/insights/redtube-brazil. Acesso em 07 jun. 2017.

RIBEIRO, Raisa Duarte. Corporalidade e Pornografia: uma análise crítica à luz dos estudos de David Le Breton. Congresso Internacional Interdisciplinar em Sociais e Humanidades. Foz do Iguaçu, n. 4, 17 p., 8 a 11 dez. 2015.

RODRIGUES, Rafaela Araújo. Autonomia da Mulher e a Violência Doméstica: análise da Ação Direta de Inconstitucionalidade ${ }^{\circ} 4.424$ sob as perspectivas feministas da autonomia. Rio de Janeiro. 2014. 105 p. Dissertação (Mestrado em Direito) - Programa de Pós-Graduação em Direito do Departamento de Direito da PUC-Rio.

SANTANA, Camilla Martins. Da pornografia à pornoteoria: desafios e reimaginações feministas. 2016. Brasília. 134 p. Tese (Mestrado em Ciências Sociais) - Departamento de Sociologia da Universidade de Brasília.

SILVA, Julio César Casarin Barroso Silva. Liberdade de expressão, pornografia e igualdade de gênero. Revista Estudos Feministas. Florianópolis, n. 1, p. 143-165, jan./abr. 2013. Disponível em: http://www.scielo.br/scielo.php?script=sci_arttext\&pid=S0104026X2013000100008\#back22. Acesso em 07 jun. 2017.

STOLJAR, Natalie. Feminist Perspectives on Autonomy. The Stanford Encyclopedia of Philosophy: Edward $\mathrm{N}$ Zalta. Disponível em: https://plato.stanford.edu/entries/feminism-autonomy/. Acesso em 07 jun. 2017.

TAVARES, Ligia Maria; LOIS, Cecília Caballero. Anotações sobre a teoria feminista do direito de Catharine MacKinnon. Revista de Gênero, Sexualidade e Direito. Curitiba, n. 2, p. 151-170, jul/dez. 2016.

VIANNA, Adriana; LACERDA, Paula. Direitos e políticas sexuais no Brasil: o panorama atual. Rio de Janeiro: Centro Latino Americano em Sexualidade e Direitos Humanos - IMS/UERJ. 2004, 127 p.

WEST, Caroline. Pornography and Censorship. The Stanford Encyclopedia of Philosophy: Edward N. Zalta. Disponível em: https://plato.stanford.edu/archives/fall2013/entries/pornographycensorship/. Acesso em 07 jun. 2017. 
